\title{
Taş Yasdanup Toprak Döşenenler: Kandiye Kuşatması Örneğinde Osmanlı Askerlerinin Metristeki Mücadele ve Yaşamı (I667-I669)
}

Veysel Göger*

"Taşs Yasdanup Toprak Dössenenler:" Struggle and Lives of the Ottoman Soldiers in Metris Exemplified During the Candia Siege (1667-1669)

Abstract $\square$ Sieges of fortresses have always taken longer compared to the pitched battles in the military history of the Ottoman Empire. An analysis of Ottoman military history shows that there are sieges that exceed weeks, months and sometimes even years. The struggle here was not just the difficulty on the battleground but was also a difficult struggle against hunger, bad health conditions, difficult climate and psychological problems caused by the everlasting sieges. Therefore, sieges of fortresses are processes troops have to overcome a series of obstacles alongside the defensive army. In the light of this approach, this study will look at the material and psychological conditions of the Ottoman soldiers during siege wars focusing on their lives in metris during a remarkable example, i.e. the siege of Candia (1667-1669).

In Candia, the soldiers spent about two and a half years in these metris. They transformed the ditches far in the back of the metris into a bazaar with various shops. The metris where the soldiers tried to protect themselves from the cannon balls, riffle attacks, bombs (humbara) and mine attacks (lăgım saldırısı) from the fortress served as a place for resting, eating and worshiping. In due time new problems emerged. Climatic difficulties like heavy rainfall, or health issues like the spread of epidemics resulted in loss of lives. In Candia the soldiers continued to pressure the fortress while enduring many of these difficulties.

Keywords: Crete, Candia Fortress, Siege, Ottoman soldiers, Metris, Köprülü Fazıl Ahmet Paşa

* Bingöl Üniversitesi. 
Köprülü Fazıl Ahmet Paşa 1666 yılının sonbaharında Girit'e ayak bastığında sırtında büyük bir yük taşıyordu. Sultan İbrahim döneminde 1645 yılında başlayan Girit seferi Osmanlı’nın daha önce görmediği uzunlukta bir savaşa dönüşmüş, çok sayıda asker kaybedilmiş, hazine ciddi anlamda boşalmış, Çanakkale Boğazı uzun süre Venedik donanmasınca kapanmıs, harp başladığında tahtta olan padişah bile değişmişti. Aslında adanın üç büyük şehrinden ikisi, Hanya ve Resmo, alınmıştı, fakat esas merkez şehir konumundaki Kandiye hala sağlam surlarının arkasında kendinden emin bir duruş sergiliyordu. Bunların farkında olarak adaya gelen sadrazam Kandiye'nin muhasarasına hemen başlamadı. Kandiye önlerine gidip kuşatma alanını ve kale-kenti keşfettikten sonra Hanya’ya dönerek kış boyu baharda yapılacak büyük kuşatma için hazırlıklar ve planlamalar yaptı. Neticede 1667 yılının Mayıs ayı geldiğinde metris yapımına başlama emri verilerek yaklaşık iki buçuk yıl sürecek mücadelenin fitili ateşlendi.

Zikredilen Girit seferi ve Kandiye muhasarasına dair yapılan bazı çalışmalar mevcut olup, bu çalışma ise şimdiye kadar yapılanlardan farklı olarak Kandiye kuşatmasının son devresinde (1667-1669) Osmanlı askerlerinin kale muhasaralarındaki mücadele ve yaşamına odaklanacaktır. ${ }^{1}$ Özellikle kuşatma boyunca askerlerin içinde kaldıkları metrisler makalenin ana inceleme alanını teşkil edecektir. Metris alanlarının yapımı, karşılaşılan sorunlar ve getirilen çözümler, müdafiler$\mathrm{le}^{2}$ olan mücadeleler, lağım savaşları, askerlerin günlük yaşantıları, psikolojik ve motivasyonel unsurlar birlikte değerlendirilecektir. Ayrıca yeri geldikçe kuşatma terimleri elden geldiğince açıklanmaya çalışılacaktır. Böylece dikkat çeken bir örneklem üzerinden Osmanlı askerlerinin kale kuşatmalarındaki yaşamlarının canlı bir hikâyesi verilecek ve bu çerçevede yapılan çalışma salt askeri bir bakış açısından çıkarak, muhasara esnasında Osmanlı askerlerinin duygu dünyasına girebilme gayreti içinde olacaktır.

Bu amaçları gerçekleştirebilmek için elimizde dikkat çeken beş mühim kaynak bulunmaktadır. Bu eserlerden dört tanesinin yazarları Kandiye kuşatması

1 Girit seferi ve Kandiye muhasarasına dair bazı çalışmalar için bkz. Ersin Gülsoy, Girit’in Fethi ve Adada Osmanlı İdaresinin Kurulması (İstanbul, TATAV, 2004), s. 127-184; Kenneth M. Setton, Venice, Austria and the Turks in the Seventeenth Century (Philadelphia: American Philosophical Society, 1991), s. 104-243; Johann Wilhelm Zinkeisen, Osmanl Imparatorluğu Tarihi (1623-1669), Nilüfer Epçeli (çev.) c. 4, (İstanbul: Yeditepe Yayınları, 2011), s. 511-606, 661-704.

2 Girit adası bu sırada Venedik elinde bulunuyordu. Ancak Kandiye kuşatması sırasında kaleye Avrupa devletlerinden yardım kuvvetleri de gelmiştir. 
sırasında Osmanlı ordusunda bulunmuşlardır. İlki kuşatma komutanının mühürdarı Hasan Ağa, ${ }^{3}$ ikincisi Osmanlı askerlerinin gediklilerinden Mustafa b. Musa, ${ }^{4}$ üçüncüsü renkli anlatımıyla meşhur Osmanlı seyyahı Evliya Çelebi, ${ }^{5}$ dördüncüsü bir Fransız olan De la Guillatiere'dir. ${ }^{6}$ Hikâyet-i Azimet-i Sefer-i Kandiye adıyla anılan beşinci eserin müellifi ise tespit edilememiştir. ${ }^{7} \mathrm{Bu}$ eserler kuşatma sürecini

3 Eserin edisyon kritiği için bkz. Abubekir Sıddık Yücel, “Mühürdâr Hasan Ağa’nın Cevâhirü’tTevârîh'i” (Yayımlanmamış Doktora Tezi, Erciyes Üniversitesi Sosyal Bilimler Enstitüsü, 1996), ilgili kısım s. 292-482. Bundan sonra, Mühürdar Hasan Ağa. Ayrıca Süleymaniye Kütüphanesi, Hamidiye Bölümü, nr. 909'da bulunan ve Kandiye kuşatmasını ihtiva eden bir eser daha vardır. Bkz. Arslan Boyraz, "Köprülüzâde Fazıl Ahmet Paşa Devrinde (1069-1080) Vukuatı Tarihi, Transkripsiyon ve Değerlendirme” (Yayımlanmamış Yüksek Lisans Tezi, Marmara Üniversitesi Türkiyat Araştırmaları Enstitüsü, 2002) çalışmanın sayfa numaralarında sorun vardır. İlgili kısımlar için bkz. vr. 35a-86a). Bu eser CevâhirütTevârîh'le karşılaştırıldığında, Kandiye muhasarası ile ilgili kısımlarda cümlelerin oldukça değiştiği fakat içeriğin çoğunlukla aynı kaldığı görülür. Ayrıca eser, kimi zaman Mühürdar Hasan Ağa dışında başka bir müellife mal edilmişse de Cevâhirüt-Tevârîh'in farklı bir tertibi olarak değerlendirilebilir. Özellikle çalışmamızla ilgili olan Kandiye kuşatması bölümünün Mühürdar Hasan Ağa’ya ait olarak anılması daha doğrudur. Makalemizde birkaç istisna dışında Sıddık Yücel'in çalışması esas alınmıştır. Mühürdar Hasan Ağa’nın bu eseri, kendisinden sonra yazılan birçok Osmanlı kroniğinin Kandiye muhasarası kısımlarının ana kaynağıdır. Bkz. Nazire Karaçay Türkal, "Silahdar Fındıklılı Mehmed Ağa Zeyl-i Fezleke (1065-22 Ca.1106 / 1654-7 Şubat 1695) (Tahlil ve Metin)” (Yayımlanmamış Doktora Tezi, Marmara Üniversitesi Türkiyat Araştırmaları Enstitüsü, 2012), s. 435-579; Râşid Mehmed Efendi, Târîh-i Râş̧id, c. I (1071-1114/1660-1703), Abdülkadir Özcan, Yunus Uğur, Baki Çakır, Ahmet Zeki İzgöer (haz.), (İstanbul: Klasik, 2013), s. 102-143.

4 Yeni tespit edilen bu eser için bkz. Mustafa bin Musa, Tarih-i Sefer ve Feth-i Kandiye, Fazıl Ahmed Paşänın Girit Seferi ve Kandiye’nin Fethi, 1666-1669, Meltem Aydın (haz.), (İstanbul: IQ Kültür Sanat Yayınları, 2016). Bundan sonra Mustafa b. Musa, Tarih-i Sefer ve Feth-i Kandiye.

5 Evliya Çelebi b. Derviş Mehemmed Zıllî, Evliyâ Çelebi Seyahatnâmesi, 8. Kitap: Topkapı Sarayı Kütüphanesi Bağdat 308 Numaralı Yazmanın Transkripsiyonu-Dizini, Seyit Ali Kahraman-Yücel Dağlı-Robert Dankoff (haz.)(İstanbul: Yapı Kredi Yayınları, 2003), s. 170254.

6 De la Guillatiere Kandiye kuşatmasının son yılının kısa bir bölümüne tanıklık etmiştir. Orjinali Fransızca olan bu seyahatnamenin erken tarihli İngilizce çevirisi kullanılmıştır, bkz. Monsieur de la Guillatiere, An Account of a Late Voyage to Athens, containing the estate both ancient and modern of that famous city, and of the present empire of the Turks, the life of the now Sultan Mahomet the IV, with the Ministry of the Grand Vizier Coprogli Achmet Pacha: also the most remarkable passages in the Turkish camp at the siege of Candia and divers other particularities of the affairs of the port, ed. ve çev. J. M. (Londra: Herringman, 1676).

7 Nuri Adıyeke, "Hikâyet-i Azimet-i Sefer-i Kandiye" (Yayımlanmamış Yüksek Lisans Tezi), Ege Üniversitesi, Sosyal Bilimler Enstitüsü, 1988). Bu kroniğin bir takım istinsah farklılıkları bulunan başka nüshaları da bulunmaktadır. Ersin Gülsoy, "Girit Seferleri Gazavâtnâmeleri 
detaylı olarak vermekte olup verdikleri bilgiler birbirini desteklemektedir. Ayrıca muhasara anlatımlarındaki ağırlık noktaları ilgi alanlarına göre değiştiğinden bu kaynakların verileri birbirini tamamlamaktadır.

\section{Ordunun Kale Çevresine Yerleşmesi}

Sadrazam Köprülü Fazıl Ahmet Paşa 1667 senesinin Mayıs ayı sonlarında, Kandiye önlerine mevcut tüm Osmanlı birlikleriyle geldiğinde, onu, orada uzun zamandır güçlükle muhasaraya devam eden askerler büyük bir merasimle karşıladılar. Sadrazam ilk olarak ordunun ileri gelenlerinden üç yüz kadarına hilat giydirerek onları kuşatma arifesinde motive etti. ${ }^{8}$ Yapılan harp divanı neticesinde, Girit Adası'nın kuzey sahilinin orta bölümünde bir tarafı denize bakan Kandiye Kalesi'nin, kuzey-doğu ve batı yönlerinden muhasaraya alınmasına, güney ve güney-doğu tarafının ise karavullarca kontrol altında tutulmasına karar verildi. ${ }^{9}$

ve Özellikler”, Yeni Türkiye, 33 (Ankara: 2000), s. 641-642; Gülsoy, Girit’in Fethi, s. XVIII). Bu eserin tam olarak orijinal bir kronik olup olmadığ kanaatimizce şüphelidir. Çünkü Cevâhirüt-Tevârîh'in Girit Seferi kısmı ile 1868 tarihinde iki ayrı müstensih tarafından istinsah edildiği düşünülen Hikâyet-i Azimet-i Sefer-i Kandiye (Adıyeke, Hikâyet-i Azimet-i Sefer-i Kandiye, s. XII) adlı eser arasında büyük benzerlikler bulunmaktadır. Özellikle konunun akışı eserin ortalarına kadar hemen hemen aynıdır. Bu kısma kadar CevâhirütTevârîh'te her yeni konu başlıklara ayrılmışken Hikâyet-i Azimet-i Sefer-i Kandiye’de başlık bulunmamaktadır. İlaveten eserin bir başka nüshası olduğu ifade edilen Tarih-i Muteber adlı kronikte, eserin müellifi olarak "Li Mühürdar-1 Sadr-1 a'zam-1 esbak fatih-i Kandiye" ibaresinin geçmesi (Agâh Sırrı Levend, Gazavât-nâmeler ve Mihaloğlu Ali Bey’in Gazavâtnâmesi (Ankara: Türk Tarih Kurumu, 2000), s. 123) Cevâhirütt-Tevârîh’in yazarı Sadrazam Fazıl Ahmet Paşa’nın mühürdarı Hasan Ağa'ya bir gönderme olarak değerlendirilebilir. Ancak tüm bunlara rağmen birbirlerinden farklı bilgiler de vermektedirler. Bu nedenle Hikâyet-i Azimet-i Sefer-i Kandiye adlı eserin Cevâhirüt-Tevârîh'in bir parçası olup olmadığ tam olarak belirlenememiştir. Bu yüzden eser verdiği farklı bilgiler göz önüne alınarak ayrı bir kronik olarak değerlendirilmeye devam edilmiştir.

8 Mühürdar Hasan Ağa, s. 326; Hikâyet-i Azimet-i Sefer-i Kandiye, s. 12-13.

9 Mühürdar Hasan Ağa, s. 326-327; Hikâyet-i Azimet-i Sefer-i Kandiye, s. 12-13; Mustafa b. Musa, Tarih-i Sefer ve Feth-i Kandiye, s. 104-105; Evliya Çelebi, Evliyâ Çelebi Seyahatnâmesi, 8. Kitap, s. 183-185. Osmanlı ordusunun Kandiye muhasarası esnasında kale önü yerleşimini gösteren çok sayıda görsel kaynak günümüze ulaşmış olup kroniklerin verdikleri bilgilerle kıyaslandığında bunların tutarlı oldukları görülmektedir. Bazıları için bkz. Dragoş Cosmescu, Venetian Renaissance Fortifications in the Mediterranean (North Carolina: McFarland, 2016), s. 187; Martha Pollak, Cities at War in Early Modern Europe, (New York: Cambridge University Press, 2010), s. 132; Bibliothèque Nationale de France, Département Cartes et Plans, GE DD-2987 (6312); GE DD-2987 (6313). Son ikisi için bkz. (Ek-2, 3). 
Hangi birlik kaleyi nereden kuşatacaksa çadırlarını o bölgeye kurdu. Ancak kurulan çadırlar, sadrazamın otağı da dâhil, kale toplarının menzilinde olduğundan ilk gece hiç kimsenin gözüne uyku girmedi. Müdafilerin top ve havan atışları çadırları parçaladığı gibi, bazı askerlerin de ölümüne neden oldu. Sabah olduğunda ordudaki herkes sorunun metrislere girilince çözüleceğini söyleyerek birbirlerini teselli ettiler. ${ }^{10}$ Ayrıca tedbir alınarak ordunun yerleşim alanı daha geriye çekildi ve sadrazamın otağı da topun zarar veremeyeceği kayalık bir yerin alt kısmına yerleştirildi. ${ }^{11}$ Çadırlar kale çevresine kurulurken su kaynaklarına yakın noktalar seçildi. Özellikle ana kuşatma bölgesi olan batı tarafında surlara paralel olarak ilerleyen Giofro Nehri'nin çevresi çadırlarla doldu ve muhasara boyunca askerin her türlü su ihtiyacı bu nehirden karşılandı. ${ }^{12}$ Neticede sadrazam bir an önce taarruza girişmek amacıyla gece vakti metrislerin hazırlanmaya başlanmasını emretti. Askerlere kazma ve kürek dağıtılarak metrislerin kazılmasına başlandı.

Metris veya meteris savaş alanında askerin muhafazası için yığılan toprak, siper, istihkâm anlamında kullanılan bir tabirdir. ${ }^{13}$ Metrisler kalenin muhasaraya alındığı her noktada surlara paralel olarak yapılırdı. İlk metris yapıldıktan sonra 'sıçan yolu' (yaklaşım yolu) olarak adlandırılan hendekler kazılırdı. Sıçan yolları, metrisler arası bağlantıyı sağlayan ve kaleye doğru kıvrılarak veya zikzaklar çizerek ilerleyen hendeklerdir. Bunların düz bir şekilde yapılmamalarının en büyük sebebi müdafilerin ateşine karşı açık alan oluşturmamaktır. İlaveten kaleden atılacak bir top güllesinin böyle bir sıçan yoluna isabet etmesi durumunda düz bir hatta dikey olarak ilerleyip hemen tüm askerleri ezebileceği de düşünülmüş olmalıdır. İlk metristen ikinci metrise doğru yapılan bu sıçan yolu bir sonraki metris için de kazılır ve sıçan yolu-metris yapma faaliyeti aynı şekilde kale hendeğine

10 Mustafa b. Musa, Tarih-i Sefer ve Feth-i Kandiye, s. 105-106. Aslında çadırların bu şekilde top menzilinde bulunacak mesafede yerleştirilmesinin 16. asrın başlarından beri tatbik edilen Osmanlı muhasara sistemine aykırı bir uygulama olduğu belirtilmelidir. Bkz. Veysel Göger, "16. Yüzyıl Osmanlı Kale Kuşatmaları (Strateji, Taktik, Kuşatma Aşamaları ve Teknolojisi)", (Yayımlanmamış Doktora Tezi, Marmara Üniversitesi Türkiyat Araştırmaları Enstitüsü, 2014), s. 75.

11 Evliya Çelebi, Evliyâ Çelebi Seyahatnâmesi, 8. Kitap, s. 180.

12 De la Guillatiere, An Account of a Late Voyage to Athens, s. 375, 400. De la Guillatiere, Osmanlı askerlerinin su ihtiyacının Giofro Nehri'nden karşılandığını ve bu nehir olmadan uzun süre kaleyi kuşatma altında tutamayacaklarını vurgular; Evliya Çelebi'nin (s. 180, 182), "ordu deresi” olarak zikrettiği ve orducu esnafının da kenarına yerleştiğini söylediği nehir de aynı yer olmalıdır. Bu nehir için bkz. Ek-3.

13 Mehmet Zeki Pakalın, Osmanlı Tarih Deyimleri ve Terimleri Sözlüğ̈̈, c. II (İstanbul: MEB, 1983), s. 494. 
ulaşılıncaya kadar tekrarlanırdı. Böylece bir kuşatma tarafındaki metrisler, birbirine paralel şekilde, her metris yekdiğerini destekleyerek kaleye doğru kademe kademe yaklaştırılırdı. ${ }^{14}$

Kandiye önlerindeki metris ve sıçan yollarının hazırlanması da bu minval üzere kuşatma boyunca devam etti. Metrisler oldukça derindi ve genişliği zeminin durumuna göre yer yer 4,5-5 metreyi (15-16 ayak) buluyordu. ${ }^{15}$ Metrislerin uygun bölgelerine 'domuz damı' olarak da adlandırılan tabyalar inşa edilerek üstlerine toplar çıkarıldı. ${ }^{16}$ Bazı tabyalar ise tüfekli askerlerin konuşlanacağı şekilde inşa edildi. Üzerleri de ağaç direkleri ve toprak yardımıyla kapatıldı. Ayrıca bazı metrislerin ön kısımlarında siperler hazırlanarak tüfekli askerler yerleştirildi. Böylece kale ateş alına alındığı gibi, metrislerin de adım adım surlara doğru yaklaştırılması nispeten kolaylaştırıldı.

\section{Metris Alanında Mücadele ve Yaşam}

Kandiye muhasarasının ilk günlerinden itibaren Osmanlı askerleri hazırlanan metrislere peyderpey yerleştirildi. Askeri bölükler küçük gruplar halinde kaleye doğru bir metristen diğerine sıçan yollarından geçerek surlara yaklaşırken müdafilerin açtıkları ateş sonucu çok sayıda kayıp veriyordu. ${ }^{17}$ İlerlemeleri kaleden yapılan huruç harekâtları nedeniyle yavaşlıyordu. Müdafilerin aniden kaleden çıkarak metris bölgesine yaptıkları saldırılar Osmanlı askerleri için tehlikeli olabiliyordu. Metris ve sıçan yolu kazan grupların bu huruç harekâtlarında yalnız kalmamaları için metrislerin gerisinde karavul denen atlı askerler bekletiliyordu. $\mathrm{Bu}$ saldırılar özellikle gece karanlığından istifade edilerek yapılmaktaydı. Kandiye kuşatması boyunca müdafiler sayısız huruç harekâtında bulundular. Öyle ki Evliya Çelebi'nin ifadesine göre müdafiler hicri 1079 (1668-69) senesi içinde sadece bir muhasara kolunda 19 defa huruç harekâtına kalkışmışlardır. ${ }^{18}$ Küçük çatışmalardan, saatleri bulan ciddi muharebelere dönüşebilen bu saldırılar muhasaranın sonuna kadar eksilmeden sürdü. Her iki taraf da bu saldırılarda önemli kayıplar verdi. Bunlar içerisinde iki tanesi dikkat çeker. İlki Aralık 1668'de yaklaşık üç saat süren bir muharebedir ve her iki taraf da çok sayıda zayiat vermiştir.

14 Göger, 16. Yüzyıl Osmanlı Kale Kuşatmalar, s. 101-102.

15 De la Guillatiere, An Account of a Late Voyage to Athens, s. 407.

16 Domuz damı için bkz. Göger, 16. Yüzyıl Osmanlı Kale Kuşatmaları, s. 103-105.

17 Mustafa b. Musa, Tarih-i Sefer ve Feth-i Kandiye, s. 106.

18 Evliya Çelebi, Evliyâ Çelebi Seyahatnâmesi, 8. Kitap, s. 194. 
Özellikle Anadolu Beylerbeyi Katırcızade Mehmed Paşa, sipahi serdengeçti ağaları ve sadrazam sekbanlarının serçeşmesi olan Veli Ağa’nın ölümünün yarattı̆̆ moral bozukluğu dikkat çekicidir. Mühürdar Hasan Ağa, ordu halkının özellikle çok sevilen Veli Ağa’nın ölümüne çok üzüldüğünü, sadrazamın dahi iki-üç gün ağlamaktan kendini alamadığını belirtir. ${ }^{19}$ İkincisi, kaleye yardıma gelen Fransız askerlerinin başını çektiği grubun Haziran 1669'da yaptığı saldırıdır. Büyük bir çatışmanın yaşanmasına sebep olan bu huruç harekâtı Osmanlı askerlerinin bariz üstünlüğü ile neticelendi. ${ }^{20}$

Kandiye kuşatması süresince kaleden yapılan huruç hareketleri ve çeşitli çatışmalar neticesinde ölen müdafilerin kelleleri sadrazam huzurunda küçük bir tepe olacak şekilde üst üste yığılmıştır. Bu işlemler büyük bir alay şeklinde kaledekilerin görebileceği yüksek bir alanda sergilenerek, müdafilerin demoralize olması hedeflenmiştir. İlaveten esir veya kelle getiren her bir askeri motive etmek için bizzat sadrazam tarafından bahşişler verilmiş ve Evliya Çelebi'ye göre bu kişilerin başına çelenkler bile takılmıştır. ${ }^{21}$

Kandiye önlerinde metrisler ilerlerken top ve havan atışları ile huruç hareketleri yanında Osmanlı askerlerinin karşısında büyük bir engel daha vardı: Lağımlar. Kale kuşatmalarında yer altında kazılan galerilere lağım denilmekte olup, Kandiye muhasarası lağım savaşlarıyla meşhur olmuştu. Hatta Zinkeisen'in deyimiyle, Kandiye kuşatması o zamana kadar görülen en muhteşem lağım muharebesiydi. ${ }^{22}$ Müdafilerin kalenin hemen bütün kuşatma cenahlarında hazırladıkları lağımlar Osmanlıların metrisleri ileri noktalara taşıma çabalarını çok zorlaştırıyordu. Müdafiler o kadar çok lağım hazırlamıştı ki metrisler bir noktadan sonra daha ileri götürülemedi. Osmanlı savaş yönetimi bu durum karşısında şimdiye kadar pek görülmeyen yeni bir uygulamayı devreye soktu. Metrislerin ulaştıkları noktalardan surlara doğru önce lağımlar kazılarak toprak altının güvenliği sağlanacak ve onu metrisler takip edecekti. Lağımlar farklı derinliklerdeki üç ayrı noktadan

19 Mühürdar Hasan Ağa, s. 421-422.

20 Mühürdar Hasan Ağa, s. 450-451; Evliya Çelebi, Evliyâ Çelebi Seyahatnâmesi, 8. Kitap, s. 196-199; Mustafa b. Musa, Tarih-i Sefer ve Feth-i Kandiye, s. 129-132; Ayrica bkz. Setton, Venice, Austria and the Turks, s. 224-225.

21 Mühürdar Hasan Ağa, s. 333, 338, 352, 376, 450-451; Mustafa b. Musa, Tarih-i Sefer ve Feth-i Kandiye, s. 132; Hikâyet-i Azimet-i Sefer-i Kandiye, s. 36-38, 47; Evliya Çelebi, "nîçe gâzîlerin başlarına Sadrı'azam kendi elleriyle gümüş çeleng takardı” (s. 183), 185-186, $197-$ 198, "bir tu[r] na teli çelenk başlarına takılup" (s. 199).

22 Zinkeisen, Osmanlı İmparatorluğu Tarihi (1623-1669), c. 4, s. 686. 
kazıldı. En dipteki lağım sekiz-on kulaç derinlikte taban suyu seviyesinde, 'püskürme' olarak da isimlendirilen toprak üstüne en yakın lağım üç kulaç derinlikte, bu iki lağımın arasındaki lağım ise orta derinlikte hazırlandı. Bunlar içerisinde en genişi taban suyu derinliğindeki lağımdı. Taban suyu, orta ve püskürme olarak da adlandırılan üçlü lağımlar, farklı kollarda ve çok sayıda kazıldı. Bu üçlü lağım sistemi yaklaşık 15-20 metre ilerledikçe, güvenliği sağlanan bu yerler üzerinden hemen metrisler yürütülüyordu. ${ }^{23}$

Lağımlar kazılırken müdafilerin hazırladığı lağımlara denk gelinebiliyordu. Yer altında lağım savaşlarına yol açan bu tür durumlar Kandiye muhasarasında çok sık gerçekleşti. Hangi taraf diğer lağımı önce tespit ederse onu etkisiz kılmaya çalıştı. Tabii öncelikle mukabil lağımların bulunması gerekiyordu. Bunun için lağım kazılırken çıkan kazma kürek seslerine odaklanıldığı görülmektedir. Eğer bir taraf diğerinin lağımını tespit ederse, kendi hazırladığı lağımın diğer lağıma en yakın noktasında bir alan açarak buraya barut yerleştirir ve bir fitil yardımıyla patlatırdı. Böylelikle lağım ve içindekiler etkisiz hale getirilirdi. Ayrıca mukabil lağıma açılan bir delik vasıtasıyla öldürücü kokular ya da duman vermek de kullanılırdı. ${ }^{24}$ Osmanlı kaynaklarında 'tütsü vermek' şeklinde geçen bu taktiğe dair önemli bir ayrıntıyı Evliya Çelebi vermektedir. Kandiye'nin alınmasından sonra kale cephanesinde bulunan malzemeler hakkında bilgi veren Evliya Çelebi avret hırızması, eşek beyni ve eşek sidiğinin de bu cephanede bulunduğundan bahseder. Bunların Osmanlı lağımlarına karşı mukabil lağımlar kazan müdafiler tarafından kullanıldığını; zikredilen bu üç şeyin ateşe verilmesi sonucu çıkan öldürücü kokunun birçok Osmanlı askerini kırdığını, kullanılan tütün dumanının ise binlerce askerin boğulmasına neden olduğunu vurgular. ${ }^{25}$ Lağıma duman vermenin bir başka yolunun humbara kullanılarak yapıldığını da Mühürdar Hasan Ağa’dan öğreniyoruz. ${ }^{26}$ Kale hendeğine doğru yaklaşılırken mukabil lağımlarla uğraşmaktan ve onların verdiği zarardan çok yıpranan Osmanlılar, yeni bir taktiğe başvurdular. Buna göre artık yer altında müdafilerin lağımları aranmayacak, kazılan lağımların en uç noktası genişçe açılarak barut yerleştirilip patlatılacaktı. Böylece hazırlanan

23 Mühürdar Hasan Ağa, s. 333-334, 339, 353; Mustafa b. Musa, Tarih-i Sefer ve Feth-i Kandiye, s. 106-107; Hikâyet-i Azimet-i Sefer-i Kandiye, s. 18; Silahdar, Zeyl-i Fezleke, s. 450.

24 Mühürdar Hasan Ağa, s. 337-342; Mustafa b. Musa, Tarih-i Sefer ve Feth-i Kandiye, s. 106107, 119; Kuşatma esnasında bizzat lağım kazan De la Guillatiere'nin lağım savaşlarına dair ifadeleri için bkz. De la Guillatiere, An Account of a Late Voyage to Athens, s. 410-411.

25 Evliya Çelebi, Evliyâ Çelebi Seyahatnâmesi, 8. Kitap, s. 211.

26 Mühürdar Hasan Ağa, s. 338. 
çok sayıdaki lağımın çevresindeki müdafi lağımları patlamanın gücüyle kendiliğinden iptal olacaktı. Ancak yeni taktik de bütünüyle sorunları ortadan kaldıra-

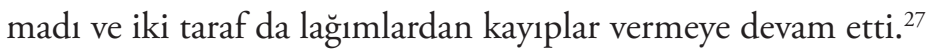

Osmanlılar, taşra tabya olarak tabir ettikleri kalenin ana tabyalarından sonra yer alan ek/dış istihkâmların önündeki hendek kenarına güçlükle yaklaştıklarında aşmaları gereken bir dizi engelle daha karşılaştılar. ${ }^{28}$ Kandiye Kalesi oldukça geniş duvarları, yıldız tabyaları, ana tabya önlerinde ravelin, taç ve boynuz sistemleri (ek istihkâmlar), derin ve geniş hendekleri ile İtalyan tarzı (trace italienne) olarak ifade edilen yeni tip kalelerin en gösterişlilerinden biriydi. ${ }^{29}$ Müdafiler bu ana savunma yapılarına ilave olarak hendeklerin kenarlarına ve içlerine şaranpo olarak ifade edilen, insan gövdesi kalınlığında ağaç direklerini kazık şeklinde yan yana dizmek suretiyle oluşturdukları setler yerleştirmişlerdi. Görüntüsünden dolayı bu setlere parmaklık da denilmiştir. Müdafiler şaranpoların arkalarına metrislenerek mücadele ediyorlardı. Ayrıca hendeğin içine domuz damları inşa etmişlerdi. Domuz damlarının üzerlerine çıkardıkları toplar ve tüfekli askerler ile Osmanlı askerlerine ateş açıyorlardı. Yine kale bedenine bitişik olarak yaptıkları bölmeler de savunma amaçlı kullanılıyordu. Şaranpo ve domuz damları ek istihkâm yapılarının gerisindeki savunma alanlarına doğru giderek çoğalıyordu. ${ }^{30}$

Osmanlı askerleri bunlara karşı hendeğin içine girip dış istihkâm duvarına ulaşmak için öteden beri uyguladıkları sistemi aynen tatbik ederek kubur denilen güvenli bir koridor oluşturdular. Buna göre hendek içinden sur dibine kadar sıçan yolu gibi toprak açılır, bu yerin üstü ağaç kütükleri, dallar ve toprak

27 Mühürdar Hasan Ağa, s. 339-342.

28 Kaymakam Mustafa Paşa’ya yazılan mektupta, taşra tabya önündeki bu hendek tabya hendeği, kalenin büyük tabyalarının önündeki ana hendek ise kale hendeği olarak tanımlanmıştır (Mühürdar Hasan Ağa, s. 354). Evliya Çelebi ise bu hendeği şöyle ifade eder; "bir seneden berü kal'anın öz vücûdunda handakı kenârın gö[r]mek değil handakdan taşra sahrâda olan on iki aded taşra tabyaların handakların göremediğimizden...(s. 183)"; "handak-1 azimden taşra olan on iki aded tabyaların başka handakları vardır kim cümle ellişer adım enli handaklar kenarınca...” (s. 218); Ve bu ulu handakdan taşra olan tabyaların başka kırkar ve ellişer adım enli ve derin handakları içinde...(s. 223).

29 Kalenin bu yapısının görseli için bkz. Ek-2, 3. Ayrıca zikredilen İtalyan tarzı kale terminolojisi için bkz. Geoffrey Parker, Askeri Devrim: Batı’nın Yükselişinde Askeri Yenilikler 1500-1800, Tuncay Zorlu (çev.) (İstanbul: Küre Yayınları, 2006), s. 15-16.

30 Mühürdar Hasan Ağa, s. 342-343, 346-347, 350, 362-363, 441; Evliya Çelebi, Evliyâ Çelebi Seyahatnâmesi, 8. Kitap, s. 183, 192, 203, 220-223; Mustafa b. Musa, Tarih-i Sefer ve Feth-i Kandiye, s. 107. 
vasıtasıyla kapatılarak müdafilerin saldırılarından korunulurdu. ${ }^{31}$ Kandiye'nin dış tabya hendeğinde kubur yapılırken aynı zamanda tabyalar da inşa ediliyordu. Müdafiler surların üstünden humbara ve taş atarak, top ve tüfekleri ateşleyerek hendeğin geçilmesini engellemeye çalıştılar. Şaranpo ve domuz damları sayesinde mukavemetleri daha da artıyordu. Ancak esas büyük zararı yine lağımlar sayesinde veriyorlardı. Hendek kenarında ve içinde bina edilen tabyalar vasıtasıyla top ve tüfek desteği alındı. Çalı, çıra veya neft yağına bulanmış paçavralar kullanılarak şaranpolar ateşe verildi. Yüzeye yakın lağımlar (püskürme) kazılarak domuz damları ve şaranpolar yıkıldı. Ancak müdafiler dağılan bir domuz damından diğerine, yakılan veya havaya uçurulan bir şaranpodan diğer bir şaranpoya sığınıyorlar, hepsinin de fevkinde attıkları lağımlarla kuburu dahi bozuyorlardı. ${ }^{32}$ Müdafilerin lağım saldırıları çok etkili boyutlara ulaşabiliyordu. Tek bir lağım ile sayıları yüzlere ulaşan asker etkisiz hale geldiği gibi, üst düzey komutanlar da bundan nasibini alıyordu. Nitekim Rumeli Beylerbeyi Hasan Paşa, bir lağım saldırısında şehit düşmüş, onun yerine geçen Kara Mustafa Paşa yine bir lağım altında kalıp ölümden dönmüştü. Aynı saldırıda sadrazam bile toprak altında kalmaktan son anda kurtarılmıştı. ${ }^{33}$ Mustafa b. Musa, bu lağım saldırısında ölen çok sayıda askerin yanı sıra yaralıların durumunu anlatırken şu canlı ifadeleri kullanmıştır: "Ve niceleri dahi mecrûh toprak altında kiminin başı taşra kalmış ve kimi beline dek gömülmüş ve kiminin kolları taşra kalmış. Allâhümme âfinâ!"34

Askerler, ciddi sayıda ölü ve yaralı vermenin, gösterilen çabaya rağmen ilerleyememenin derin üzüntüsündeydi. Ayrıca beraber mücadele ederken lağım saldırılarında ölen arkadaşlarının başlarının önce surlarda sergilendiğini, ardından müdafilerce havan toplarına konularak metrislere firlatıldığını gördükçe daha da kederleniyorlard.${ }^{35}$ Üstelik sorunlar sadece bunlardan ibaret değildi. Zaman ilerledikçe orduda iaşe malzemesi azaldığından yardım gemilerinin gerekli malzemeleri getirmesi gerekiyordu. Fakat özellikle Venedik gemileri Girit Adası'nın

\section{Göger, 16. Yüzyıl Osmanlı Kale Kuşatmaları, s. 119-120.}

32 Mühürdar Hasan Ağa, s. 342-356. Ayrıca İstanbul Kaymakamı Mustafa Paşa’ya gönderilen mektuplarda da bu olaylar özetlenmiştir. Bkz.s. 353-356, 361-363.

33 Mühürdar Hasan Ağa, s. 357. Rumeli Beylerbeyi Hasan Paşa’nın ölümünü (2 R. 1078/21 Eylül 1667) takiben, aynı ay içinde ve sonraki aylarda borçları konusunda ordu içinde çeşitli davalar görülmüştür (Başbakanlık Osmanlı Arşivi (BOA), Yabancı Arşivler-Bulgaristan Arşivi (YB).04, 2/85, s. 1-3; 2/86, s. 1-3; 2/88, s. 3).

34 Mustafa b. Musa, Tarih-i Sefer ve Feth-i Kandiye, s. 108-109.

35 Mühürdar Hasan Ağa, s. 360. 
etrafını çevirerek ${ }^{36}$ Osmanlı yardım gemilerini engellediklerinden muhasaradaki askerler sıkıntıya düştü. Ekmek, peksimet, et, pastırma, at yemi gibi gerekli birçok malzeme ordu esnafı elinde azaldığından fiyatları yüksek oranda arttı. Durum o hale gelmişti ki yaralıların tedavisinde de kullanılan tavuk yumurtası dahi kıtlıktan bulunamaz oldu. ${ }^{37}$ Zaman içinde iaşe sorunu çözülse de diğer konularda çok yavaş ilerleme sağlanabildi.

Sadrazam günde birkaç kez bizzat metrislerde dolaşarak hem durumu kontrol ediyor hem de askere moral veriyordu. Aslında moral, ekmek, su gibi ihtiyaç duyulan bir şeydi. Askerin mücadele azminin diri tutulması zafere ulaşmanın en kuvvetli amillerinden biriydi. Bunun için ordu içinde her bir nefer gösterdiği başarı ölçüsünde hemen orada nakdi olarak ödüllendiriliyordu. Ayrıca komutanlar için de önemli bir ritüel mevcuttu. Muhasara başından itibaren padişah IV. Mehmet düzenli şekilde sadrazama, hattı hümayunlarıyla beraber hediyeler gönderiyordu. Hattı hümayunlar ileri gelen askeri erkân arasında seslice okunur, gönderilen hediyeler padişah adına sadrazama takdim edilerek onurlandırılırdı. Bu hediyeler ekseri kürk, kaftan, kılıç ve hançer olurdu. Sadrazam bunları o mecliste görkemli bir şekilde şerefle giyer ve kuşanırdı. Padişah ileri gelen askeri erkâna da hediye gönderebilirdi. Böyle durumlarda padişahın mutlak vekili olan sadrazam alt rütbelilere hediyeleri dağıtarak onları taltif ederdi. ${ }^{38}$ Zaman zaman yapılan bu ritüel sayesinde morali yükselen komutanlar emirlerindeki askerleri daha da gayrete getiriyorlard.

Padişahın gönderdiği hatt-1 şerifler incelendiğinde askere hitap edilirken "din ü devletim uğruna taş yasdanup toprak döşenen gazi ve mücahid kullarım” ibaresi oldukça dikkat çekmektedir. ${ }^{39}$ Padişah uzun süre muhasarada bulunan askerlere hitap ederken "taş yasdanmak" ve "toprak döşenmek" deyimlerini kullanmakla, ne kadar büyük, zorlu bir görevde olduklarının ve çektikleri sıkıntıların farkında olduğunu belirtmektedir. Çekilen çile, acizlik, çaresizlik, üzüntü ve zorluklara

36 Zinkeisen, Osmanlı İmparatorluğu Tarihi (1623-1669), c. 4, s. 688.

37 Evliya Çelebi, Evliyâ Çelebi Seyahatnâmesi, 8. Kitap, s. 181.

38 Abdurrahman Abdi Paşa, Vekâyi 'nâme [Osmanlı Târihi (1648-1682)], Tahlil ve Metin Tenkidi, Fahri Çetin Derin (haz.) (İstanbul: Çamlıca Basım Yayın, 2008), s. 246, 313; Mühürdar Hasan Ağa, s. 330, 359, 361-362, 408-409, 424-426; Hikâyet-i Azimet-i Sefer-i Kandiye, s. 16, 40; Evliya Çelebi, Evliyâ Çelebi Seyahatnâmesi, 8. Kitap, s. 191. Kandiye muhasarasında bulunan üst düzey asker ve devlet görevlilerine çeşitli tarihlerde verilen hilatlere dair kayıtlar için bkz. BOA, İbnülemin-Hil'at (İE.HLT.), 1/92, s. 1, 3; 1/93, s. 1.

39 Mühürdar Hasan Ağa, s. 330, 408; Hikâyet-i Azimet-i Sefer-i Kandiye, s. 16, 40. 
katlanmak gibi durumlar için kullanılan bu deyimler, ${ }^{40}$ Kandiye kuşatmasında bulunan askerler için çok gerçekçi ve tanımlayıcı olmuştur. Ömürlerinin yaklaşık iki buçuk yılını, kış ayları da dâhil, metrislerde geçiren askerler bir bakıma, toprağı kendilerine döşek, taşları da yastık yapmışlardı.

1667 yılının son aylarına gelindiğinde büyük uğraşlar sonucu kalenin batı tarafındaki ek istihkâmlarından biri alındı. Bir diğerinin de yarısı ele geçirildi. Böylece birkaç noktada kale duvarları ile büyük tabyaların önündeki ana hendek kenarına ulaşıldı. ${ }^{41}$ Ancak daha fazla ilerlenilemediği gibi kış da yaklaştığından kalenin ele geçirilmesinin uzayacağı net olarak anlaşılmıştı. Yapılan harp divanında, altı ayı aşkın sürede ancak kalenin ana hendeğine ulaşılabildiği ifade edilerek, mevcut kazanımların elden çıkmaması için kışı metrislerde mücadele halinde geçirmeye karar verildi. Metrislerin tabanına kaldırım döşendi. Hendek başlarında yeni tabyalar inşa edildi. Bu tabyaların etrafı, müdafilerin yapacağı lağım saldırılarından emin olmak amacıyla taban suyu seviyesine kadar kazıldı. Askerler kışın yağmur, kar ve soğuğundan, müdafilerin ateşinden özellikle de havan toplarından korunmak için metrislerde kulübe ve meskenler yaptılar ve bu meskenlerin üstlerini tahta ve keresteler ile kapattılar. Bazıları metris kenarlarında yer altına mahzenler kazdılar, kimileri de sıçan yolu başlarında, metris ağızları ve yollarında bulunan çadırlarda kaldılar. Sadrazam için de sıçanyolu başında bir kışla evi inşa edildi. Böylece bütün kışı metris alanında geçirmek için gerekli önlemler alındı. ${ }^{42}$

Muhasaranın uzaması durumunda kale önünde kışlanılacağı daha kuşatma başlamadan sadrazam tarafından düşünülmüş olmalıdır. Nitekim Kandiye Kalesi'ne yakın bir mevkide bulunan İnadiye Kalesi ve varoşu, 1650'den beri Osmanlı askerlerinin bir yerleşim alanı ve kışlağı olarak kullanılıyorken, sadrazam Kandiye'nin son kuşatması öncesi neredeyse büyük bir kasaba haline gelen

40 Bir İstanbul Hanımefendisi Sâmiha Ayverdi'den Türkçe’nin Nakışları: Atasözleri, Deyimler, Tekerlemeler, Bilmeceler, Kâzım Yetiş (haz.) (İstanbul: Kubbealtı Neşriyat, 1993), s. 339; Ozan Yılmaz, “'Gelenekten Deyişe’ Klasik Türk ve Fars Edebiyatlarının Ortak İfade Biçimlerinden 'Başa Toprak Saçmak' ” TÜRÜK, Dil, Edebiyat ve Halkbilimi Araştırmalar Dergisi, 2 (2013), s. 345-346.

41 Mühürdar Hasan Ağa, s. 359-362, 404. Batı tarafında Panigrad tabyası önünde ele geçirilen bu ek istihkâmlar Ek-2'de 26 ve 27 numarayla işaretlenmiş yerlerdir.

42 Mühürdar Hasan Ağa, s. 364-367; Mustafa b. Musa, Tarih-i Sefer ve Feth-i Kandiye, s. 109110. 1669 yilında bu meskenleri gören De la Guillatiere, (An Account of a Late Voyage to Athens, s. 376-378), on binlerce asker için ana yapı malzemesi kerpiç olan çok sayıda kulübe ve barınak yapıldığını, üst düzey rütbeli kişiler için konaklar inşa edildiğini, veziriazamın konağının duvarlarında malzeme olarak taşın da kullanıldığını belirtir. 
İnadiye varoşunda bulunan binaları yıktırmış, elde edilen kereste ve ahşapları Kandiye önünde ordunun mesken ihtiyacı için sarf etmişti. Ayrıca dönemin çağdaş şairlerden Marinos Tzane Bounialis, Fazıl Ahmet Paşa’nın İnadiye varoşunu yıktırmasının, askerlerin kaleyi fethetmedikleri sürece canlı kalmayı ya da geri dönmeyi umut etmemelerini sağlamak gibi bir psikolojik amaca da hizmet ettiğini ifade eder. ${ }^{43}$

Evliya Çelebi, kuşatma başında kalenin batı tarafında, metrislerin gerisinde kuzey-güney çizgisinde boydan boya büyük bir sıçan yolunun inşa edildiğini ve bunun iki tarafının baştan sona bir şehir çarşısını andıracak şekilde yaklaşık altı ayda tamamlandığını belirtir. ${ }^{44} \mathrm{Bu}$ sıçan yolunun kenarlarında her türlü şeyin satıldığı dükkânlar ile birçok sanat erbabı da vardır. İlerleyen zamanlarda Zağarcıbaşı Zülfikar Ağa tarafından yeni yapılan bir sıçan yolunun öncekinden daha iyi bir şekilde hazırlandığını ve bu sıçan yolunun kenarlarında bakkal, kasap, bozahane gibi dükkânların olduğunu zikreder. Benzer şekilde kalenin doğu tarafında da metrisler içinde sebilhane, gasilhane ve kahvehanelerin yapıldığını ifade eder. Ayrıca ordu içinde çok sayıda hekim, cerrah ve gasilhane çadırının bulunduğunu; 160 yerde mescid, 40 yerde hamam ve üç bin yerde sebilhane olduğunu vurgulayan Evliya Çelebi, tahıl, koyun, balık ve eşek pazarları hakkında da bilgi verir. ${ }^{45}$ Bunların sayıları şüpheli olsa da mevcudiyetlerine dair herhangi bir şüphe bulunmamaktadır.

Osmanlıların sefer organizasyonu içerisinde askerin giyim, yiyecek içecek, sağlık, silah ve donanım gibi ihtiyaçlarını ücret karşılığı temin eden orducu esnafi, ${ }^{46}$

43 İnadiye varoşunun yıktırılması olayını Osmanlı ve Venedik kaynakları doğrulamakta olup ayrıca şair Marinos Tzane Bounialis'in ifadesi için bkz. Elias Kolovos, "A Town For the Besiegers: Social Life and Marriagein Ottoman Candia Outside Candia (1650-1669)", The Eastern Mediterranean Under Ottoman Rule: Crete, 1645-1840 (Halcyon Days in Crete VI A Symposium Held in Rethymno13-15 January 2006) içinde Antonis Anastasopoulos (ed.) (Rethymno, Crete University Press, 2008), s. 107.

44 Evliya Çelebi her ne kadar bu uzun hendeği sıçan yolu olarak ifade etmişse de daha önce zikredildiği üzere, kuşatma terminolojisi içinde, kaleye doğru zikzak çizerek ilerleyen hendeklere sıçan yolu denilmektedir. Evliya Çelebi, belki şeklinden dolayı, kaleye paralel olarak yapılmış bu hendeği de aynı şekilde tanımlamıştır.

45 Evliya Çelebi, Evliyâ Çelebi Seyahatnâmesi, 8. Kitap, s. 180-181, 184-185, 190.

46 İstanbul, Bursa ve Edirne üç büyük merkez olarak seferlere orducu çıkardığı gibi, imparatorluğun farklı eyalet ve sancaklarından da orducular seferlere iştirak ediyorlardı. Bkz. Şenol Çelik, "Orducu”, Türkiye Diyanet Vakfi İlâm Ansiklopedisi (TDVİA), c. XXXIII, s. 370-371; aynı müellif, "Osmanlı Sefer Organizasyonunda Orducu Esnafı ve İstanbul Orducuları”, Eskiçăğdan Modern Çăğa Ordular: Oluşum, Teşkilât ve İslev içinde Feridun 
Kandiye muhasarası için de görevlendirilmişti. ${ }^{47}$ Kandiye önlerinde kışlayan askerler de devlet tarafından verilenler dışında ihtiyaçlarını buradan karşılamaya çalıştılar. Tabii bunun için ellerinde para olması gerekliydi. Kapıkulu askerleri maaşı olduklarından kış süresince bir sorun yaşamadılar. Vakitleri geldiğinde metrislerde herkese maaşı dağıtıldı. Ayrıca sefer esnasında ekmek, et ve pirinç gibi temel ihtiyaçlarının önemli bir kısmını maaşlarına ilaveten alıyorlardı. Örneğin, 1669 yılında metrislerde bulunan De la Guillatiere, maaşlı askerlere günde yaklaşık yarım kilo ekmek, dört günde bir 6 ons (yaklaşık 170 gr.) et tahsis edildiğini, ayrıca altı askere bir tabak pilav verildiğini zikretmektedir. ${ }^{48} \mathrm{Bu}$ konuda esas sorun yaşayanlar tımarlı sipahilerdi. Yanlarında getirdikleri paralar kuşatmanın uzaması yüzünden bayağı azalmıştı ve çeşitli şekillerde ellerine geçen inamlarda onları bir yere kadar götürebilirdi. Bu durum karşısında Rumeli ve Anadolu tımarlı askerlerinin her yirmi beşinden biri harçlıkı tayin edilerek Nevruz zamanı gelmek şartıyla donanmayla bölgelerine gönderildiler. Böylece ordu içinde oluşabilecek bir soruna önceden tedbir alındı. ${ }^{49}$

İaşe sorunu önemli ölçüde çözülse de kış vakti metrislerde oldukça zor geçiyordu. Yağan yağmurlara bazı günler kar ve dolu da ekleniyordu. Kimi zaman yağışın şiddeti daha da artıyordu. Öyle ki Ocak ayında bir ara hiç durmadan yedi gün yedi gece yağmur yağdı. ${ }^{50}$ Aşırı yağışlar sonucu metrislerde oluşan sulu balçık askerlerin beline kadar çıktığında hayatı zorlaştırıyor ve hareketleri kısıtlıyordu. ${ }^{51}$ Bunlara sefer başından beri orduyu tehdit eden hastalıklar da eklenmeye başladı. ${ }^{52}$ Humma ve veba (taun) çok sayıda askerin ölümüne neden oldu. ${ }^{53}$ Birçoğu da

Emecen (ed.) (İstanbul: Kitabevi, 2008), s. 360, 362, 365-367; Bülent Çelik, "Osmanlı Seferlerinin Lojistik Sorunlarına Kentli Esnafın Getirdiği Çözümler: Orducu Esnafı" (Yayımlanmamış Doktora Tezi, Ankara Üniversitesi Sosyal Bilimler Enstitüsü, 2002), s. 92-96. Ayrıca Kandiye önlerinde bulunan ordugâhtaki pazarlarda Girit reayası da ürünlerini satiyordu.

47 Gülsoy, Giritin Fethi, s. 209-210.

48 De la Guillatiere, An Account of a Late Voyage to Athens, s. 400.

49 Mühürdar Hasan Ağa, s. 367. Girit seferinin önceki senelerinde de harçlıkçı uygulamasına gidilmişti. Bkz. Ömer Lütfi Barkan, “Timar”, İA, c. 12/1, s. 328.

50 Mühürdar Hasan Ağa, s. 371.

51 Boyraz, Köprülüzâde Fazıl Ahmet Paşa Devrinde (1069-1080) Vukuatı Tarihi, vr. 52b; Silahdar, Zeyl-i Fezleke, s. 479.

52 Mustafa b. Musa, Tarih-i Sefer ve Feth-i Kandiye, s. 101.

53 Mühürdar Hasan Ağa, s. 367. Girit seferi sırasında Venedikliler adadaki su kuyularını ve otlakları zehirledikleri gibi Osmanlı kuvvetleri arasında veba salgını çıkartmak için bir plan 
uzun rahatsızlık sürecinden sonra kendilerini toparlayabildiler. Evliya Çelebi de kuşatma esnasında sıtma hastalığından ciddi anlamda sıkıntı çekmiş ama sonunda kurtulmuştu. ${ }^{54}$ Ancak bu zikredilen koşullara karşı direnme esas mücadele bile değildi. Çünkü muhasara savaşı kış mevsimine rağmen bir an bile durmadı. Müdafilerin lağım saldırıları, top, tüfek ve havan atışları aralıksız devam etti. Osmanlılar hem kış koşullarına direnmek hem de kuşatma hatlarını korumak için nöbet sistemini uyguladılar. Korunaklı şekilde inşa ettikleri tabyalarda belirlenen gruplar birer gün nöbet tutuyordu. Örneğin bir kuşatma kolunda sırayla, sadrazam kethüdası taifesi ve bin nefer sekban, Rumeli Beylerbeyi emrindeki tımarlı askeri, sancak beyleri ve birkaç sancak askeri, yeniçeri kethüdası emrindeki askerle dörtlü nöbet oluşturacak şekilde çatışma alanındaki tabyalarda bulunuyorlardı. ${ }^{55}$

İmparatorluğun çeşitli bölgelerinden gelip Kandiye önlerinde savaşan kimi neferlerin ailelerini özlemeleri ve ölmeleri halinde geride bıraktıklarının akıbetlerini derin derin düşünmeleri olası şeylerdi. Belki de bu endişeli kişiler arasında bulunan Kayserili lağımcı Receb'in korktuğu başına geldi ve 1668 senesinin ilk yarısında vefat etti. Geriye küçük yaşlarda Hamza, Mustafa, Mahmud ve Rahime adında üç erkek ve bir kız çocuğunu yetim bıraktı. ${ }^{56}$ Lağımcı Receb’in hemşerisi olan Şamlu Mustafa ise üç yıldır Kandiye kuşatmasında bulunuyordu. Anlaşılan Fazıl Ahmet Paşa’nın keşif için Kandiye'ye geldiği sırada onu karşılayıp yıllardır Girit Adası'nda "yetim" kaldıklarını söyleyen ve akabinde "bangır bangır" ağlayan askerler arasında o da vard1.${ }^{57}$ Daha sefere çımadan önce ne olur ne olmaz diyerek köle ve cariyesinin savaşta ölmesi halinde azat edilmesini istemiş ve bu işi yapmak için vekili olarak Ömer Çelebi'yi bırakmıştı. Nitekim Şamlu Mustafa da hemşerisiyle aynı akıbete uğradı ve vasiyeti yerine getirildi. ${ }^{58}$

1668 yılının ilkbahar ayları geldiğinde, Osmanlılar ikinci sene yapılacak büyük saldırı için gerekli hazırlıklara başladılar. Merkezden önemli sayıda asker

da hazırlamışlardı (Gabor Agoston, “Avrupa'da Osmanlı Savaşları: 1453-1826”, Osmanlida Savaş ve Serhad, Kahraman Şakul (çev.) (İstanbul: Timaş Yayınları, 2013), s. 94.

54 Evliya Çelebi, Evliyâ Çelebi Seyahatnâmesi, 8. Kitap, s. 182.

55 Mühürdar Hasan Ağa, s. 371.

56 Murtaza Çevik, “78/1 Numaralı Kayseri Şer’iyye Sicili (H. 1078-1079/M. 1668), Transkripsiyon ve Değerlendirme” (Yayımlanmamış Yüksek Lisans Tezi, Erciyes Üniversitesi Sosyal Bilimler Enstitüsü, 2009), s. 209.

57 Hikâyet-i Azimet-i Sefer-i Kandiye, s. 7; Mühürdar Hasan Ağa, s. 311.

58 Musa Sezer, “78/2 Numaralı Kayseri Şer’iyye Sicili (H. 1078-1079/M. 1668), Transkripsiyon ve Değerlendirme” (Yayımlanmamış Yüksek Lisans Tezi, Erciyes Üniversitesi Sosyal Bilimler Enstitüsü, 2008), s. 109-110. 
ve iaşe takviyesi alınd.. ${ }^{59}$ Müdafilerin attıkları top gülleleri düştükleri yerlerden getirilerek toplandı. Ancak mevcut topların çapı bu gülleleri atmak için uygun olmadığından, daha önce Kandiye' ye yakın bir mevkide bina edilmiş tophanede ${ }^{60}$ sadece bu gülleleri atmak için üç tane top döküldü. Deniz yoluyla yardım almasını engellemek amacıyla kalenin kuzey doğu ve kuzey batı tarafının sahil kenarına toplar yerleştirildi. Hatta kalenin tüm kıyı kesimini ateş altına almak için kıyıda denize bir miktar toprak dolgu yapılarak buraya da toplar konuşlandırıldı. ${ }^{61}$ Osmanlı topçuları gece karanlığından istifade edip kaleye yardıma gelen her türlü deniz aracını tespit etmek gayesiyle, humbara yüklü havan toplarını deniz üstüne doğru atarak bir nevi aydınlatma fişeği olarak kullanıyorlardı. Yine deniz üstünü aydınlatmak için zaman zaman derya yüzüne zift, kükürt ve barutla dolu toplar da ateşleniyordu. ${ }^{62}$

Zaman ilerleyip sıcaklar artınca ilk yılda olduğu gibi yeniden bütün askerler, kendileri için belirlenmiş muhasara kollarına yerleştirildiler. 30 Haziran 1668 Cumartesi günü Sabah namazı birlikte kılındıktan sonra zafer için topluca dualar edilip akabinde kurbanlar kesildi. Sancaklar ve bayraklar dikilip, davullar çalınırken taarruza başland $1 .{ }^{63}$ Kuşatma savaşlarında genellikle muhasara başı ile umumi hücumlardan evvel yapılan ve önceki yüzyıllarda da sıkça görülen bu dini ritüelin temel hedefi, İslâmi gaza ruhu uyandırılarak askeri manen motive etmek ve ölüm korkusunun olabildiğince azaltılmasını sağlamaktı. ${ }^{64}$

Metristeki tabyalarda toplar kale duvarını, sur üstündeki top mazgallarını ateş altına alırken askerler surlara yaklaşmak için çaba içindeydi. Daha önce kararlaştırılan bölgelerde ise yeni metris yapımına başlandı. Kalenin batı kesiminde denize yakın noktada yer alan ve Osmanlıların Kızıl Tabya dedikleri tabyanın

59 Gönderilen çeşitli mühimmat için bkz. BOA, Maliyeden Müdevver Defterler (MAD.), 4026. Mesela, 27 Mayıs 1668 'de 100 adet top kundağı, 210 tane top tekerleği ile 17346 adet humbara gönderilmiştir (MAD., 4026, s. 159).

60 Evliya Çelebi, s. 179. Ayrıca bkz. Boyraz, Köprülüzâde Fazıl Ahmet Paşa Devrinde (10691080) Vukuatı Tarihi, vr. 56a, 58a-b. Bu tophanenin kuruluşu, mevkii ve üretim faaliyetleri için bkz. Veysel Göger, "Osmanlıların Kandiye Kuşatması Sırasında Girit Adası'nda Kurdukları Tophane (1666-1670)”, Türk Kültürü Incelemeleri Dergisi, 38 (İstanbul 2018), s. 107-126.

$61 \mathrm{Bu}$ topların yerleşim görünümü için bkz. Ek-2, 3 .

62 Mühürdar Hasan Ağa, s. 382-384, 399, 404-406; Hikâyet-i Azimet-i Sefer-i Kandiye, s. 20, 29.

63 Mühürdar Hasan Ağa, s. 406; Hikâyet-i Azimet-i Sefer-i Kandiye, s. 28.

64 Göger, 16. Yüzyıl Osmanlı Kale Kuşatmaları, s. 180-182. 
karşısı sade kayalık bir alandı. Bu bölgenin altında müdafilerin lağım kazmasının zor olduğu düşünüldüğünden burada bir muhasara kolu oluşturulmaya çalış1dı. Ancak kayalık alan kazılamadığından askeri koruyacak metris hendeklerinin hazırlanması için yeni bir çare düşünüldü. Neticede metrislerin yapılabilmesi ve askerin emniyet altında surlara doğru ilerleyebilmesi için gerekli malzemenin geri bölgelerden taşınmasına karar verildi. Bu iş çok zor ve yorucu olduğundan fazla sayıda adama ihtiyaç vardı. Bu sebeple orducu esnafı ve kâtipler gibi ordunun normalde muharip unsurları olmayan grupları dahi bu işe koşuldu. Belirlenen bir sistem içerisinde uzak noktalardan torbalar dolusu toprak ve çalı taşınarak getiriliyor (toprak sürmek), kayalık alan üzerinde metrisler yapılıyordu. Nöbetleşe bir usül ile toprağın taşınması sürekli hale getirildi. Sadrazam tevabii, orducular, defterdar ile kâtipler, silahdarlar ve sipahiler, ayrı gruplar şeklinde beşli nöbet sistemiyle toprak sürüyorlardı. Metrisler başarıyla dış tabyaya doğru yaklaştırıldı ve fazla zaman harcamadan burası ele geçirilerek kalenin ana duvarının önündeki hendeğe girildi. ${ }^{65}$ Osmanlıların öteden beri uyguladıkları toprak sürmek faaliyeti çoğunlukla kale hendeğinin doldurulması ve havale kulelerinin inşası için yapılırken, ${ }^{66}$ bu örnekte görüldüğg̈ üzere yeni bir muhasara kolunun tamamının teşekkülünde uygulanmıştır.

Kalenin kuzey-doğu tarafında Osmanlıların Küllük/Güllük diye adlandırdıkları bölgede de yeni bir kuşatma kolu hazırlanıyordu. Buranın kumluk bir arazi yapısına sahip olması sebebiyle yine müdafilerin lağım saldırısını engelleyeceği düşünülmüştü. Ancak müdafiler kubura benzeyen bir şekilde sandıklardan çatma lağımlar meydana getirdiklerinden, ${ }^{67}$ Osmanlı askerleri ancak yoğun uğraşlar sonucu kale hendeğine ulaşabildiler. ${ }^{68}$

Kuşatmanın bu ikinci yılında ordunun metrislere yerleşip mücadelenin başladığı sırada, aslında askerler önceki uzun yılın bir benzerinin gerçekleştiğinin

65 Mühürdar Hasan Ağa, s. 406-407, 410-411; Hikâyet-i Azimet-i Sefer-i Kandiye, s. 28-29.

66 Göger, 16. Yüzyıl Osmanlı Kale Kuşatmaları, s. 127-133.

67 Boyraz, Köprülüzâde Fazıl Ahmet Paşa Devrinde (1069-1080) Vukuatı Tarihi, vr. 58b; Silahdar, Zeyl-i Fezleke, s. 506. Mühürdar'ın Cevâhirü̈t-Tevârîbi'nin başka bir tertibinden/ nüshasından faydalandığını düşündüğümüz ve hemen tamamı kendisinden önceki kaynaklardan olduğu gibi alıntı yapılarak oluşturulmuş bir derleme eserde, bu lağımları müdafilerin kubur ile kum içinde yürüyerek yaptıkları ifade edilmiştir. Bkz. Ayşe Pul, Girit Savaşı İle İlgili Bir Türk Kaynağının Tahlili (TTK Kütüphanesi’nde Bulunan Girid Fethi Tarihi Başlıklı Yazma) (Yayımlanmamış Doktora Tezi, Ankara Üniversitesi Sosyal Bilimler Enstitüsü, 2004), s. 174.

68 Mühürdar Hasan Ağa, s. 410-411; Hikâyet-i Azimet-i Sefer-i Kandiye, s. 29. 
farkında olarak adeta dejavu yaşıyor gibiydiler ve korku ve ümit arasındaki gelgitde kimi zaman ümitsizlik ağır basabiliyordu. Kuşatma ordusunun bir neferi olarak içerden bilgi veren Mustafa b. Musa çatışmaların yoğunlaştı̆̆ı zamanlarda askerlerin bu hissiyatını şöyle yansıtmıştır: "Acabâ böyle kalursa bu ortalık hâli, nice olur hâlimiz? Kal'anın her bakdıkça metâneti akla sığmaz ve vasfa gelmez. Ve içinde olan cengci küffârının hîlesi ve mekri ve tedârikine akıl yetmez, hemân hâlimiz cenâb-1 Hakk'a kalmışdır' deyü herkes kendüden me'yûs olmuşlar idi." ${ }^{69}$

Zaferin etkin bir mücadeleden geçtiğinin bilincinde olan Osmanlı savaş yönetimi, ordunun psikolojik durumunu göz önüne alarak, askerlerin mücadele azmini diri tutmak için en ufak bir başarıyı hemen ödüllendirmeye muhasara süresince devam etti. Kuşatma kollarında kale duvarına ilk olarak ulaşıp el vuran kişiye sadrazam kendi eliyle ihsanda bulundu. Kale duvarından bir taş parçası koparan ilk kişi de ödüllendirildi. Yine lağımların karşılaşması esnasında yer altında müdafilerle başarıyla mücadele eden askerler de bu yüz aklıklarının karşılığını ödül olarak aldılar. ${ }^{70}$ Tabii ön saflarda çatışmak gibi en tehlikeli görevlerde bulunmak daha büyük ve cezbedici ödüllerle teşvik ediliyordu. Osmanlılar, bunun için zaman içinde geliştirdikleri bir sistemi uygulamışlardır. Serdengeçtilik olarak tarihe geçen bu sistem, ilk zamanlar sadece savaş esnasında ve özellikle profesyonel askerler arasında tatbik edilse de zaman içinde ülkenin çeşitli yerlerinden ve farklı sınıflarından kişilerin de dâhil edildiği muazzam bir hale geldi. Tamamen gönüllülük esasına dayanan bu sistemde, farklı gruplardaki askerler isteğe bağlı olarak ihtiyaç oranında deftere kaydedilirdi. İlaveten bu deftere, kişilerin başarıları durumunda hangi paye ve/veya maddi kazancı elde edecekleri önceden yazılarak gönüllülere garanti verilirdi. Osmanlı askeri tarihine dair önemli bir eser kaleme almış olan Rhoads Murphey, bu sistemde iyi eğitilmemiş kişiler yerine profesyonel askerlerin kullanılmasına dikkat çekmektedir. Ona göre bu kategoride hizmete kaydedilecek fertlerin, umutsuz ve korkusuz maceraperestler yerine, her koşul altında en tehlikeli görevlerde başarı kazanabilecek deneyimli savaşçılar olmaları hedeflenmiştir. ${ }^{71}$ Murphey'in bu gözleminin yanısıra tarihi süreç içinde

69 Mustafa b. Musa, Tarih-i Sefer ve Feth-i Kandiye, s. 110.

70 Mühürdar Hasan Ağa, s. 411, 414. Ayrıca bkz. Jean Chardin, Chardin Seyahatnamesi; İstanbul, Osmanlı Topraklar, Gürcistan, Ermenistan, İran 1671-1673, Ayşe Meral (çev.) (İstanbul: Kitap Yayınevi, 2014), s. 82-83.

71 Rhoads Murphey, Osmanlida Ordu ve Savaş 1500-1700, M. Tanju Akad (çev.) (İstanbul: Homer Yayınevi, 2007), s. 189. 
kuloğulları, tımarlı sipahiler ve birçok farklı sınıftan kişinin de serdengeçti olabildiği belirtilmelidir. ${ }^{72}$

Kandiye kuşatmasında da serdengeçtilik sistemi düzenli şekilde işledi. Hem muhasara esnasında ordu içinde savaşan askerler arasında serdengeçtiler deftere kaydediliyor hem de merkezden zaman zaman serdengeçti olarak yazılan kişiler Kandiye’ye gönderiliyordu. İlk yılın sonunda kapıkulu süvarilerinin aşağı bölüklerinden 400 nefer, hendek başındaki tabyaları beklemek şartıyla sipahi serdengeçtisi oldular. Yine Nisan 1668 'de onar akçe terakki şartıyla sipahi ve silahdar ocaklarının her birinden 100'er kişi serdengeçti olarak tahrir edildi. ${ }^{73} 1668$ senesinin ilk yarısında ise bizzat padişahın kontrolünde üç bin civarında serdengeçti kayda geçirildikten sonra Girit'e yolcu edildi. Sonraki zamanlarda da Kandiye kuşatmasına destek için çok sayıda serdengeçti gönderilmeye devam etti. ${ }^{74}$ Serdengeçtiler kuşatma esnasında en tehlikeli görevlere koşuluyorlardı. Açılan lağımları beklemek, lağım içinden kale tarafına geçerek saldırmak, ön saflardaki metris ve sıçan yollarında savaşmak, kale hendeğindeki tabyalarda mücadele etmek bunlardan bazılarıydı. ${ }^{75}$ Yaptıkları görevler yüksek düzeyde ölüm riski taşıyordu. Nitekim çoğu zaman her koldaki serdengeçti neferâtı kayıplar yüzünden yenilenmesine rağmen yeni gidenlerin ekserisi şehit oluyor, bir kısmı da yaralanarak geri dönüyordu. ${ }^{76} \mathrm{Bu}$ nedenle Kandiye muhasarasında ölen askerler arasında serdengeçtiler bir hayli yekûn tutmuştur. Bir kaynağa göre kuşatma boyunca ölen sadece sipahi serdengeçti sayısı 49.635 kişidir. ${ }^{77}$ Evliya Çelebi ise bu sayıyı 19.045 olarak

72 Zamanla çok farklı uygulama alanlarını içine alarak genişleyen bu sistem için şimdilik bkz. Abdülkadir Özcan, "Serdengeçti”,TDVİA, c. XXXVI, s. 554-555; Temel Öztürk, Osmanluların Kuzey ve Doğu Seferlerinde Savaş ve Trabzon (Trabzon: Serander Yayınları, 2011), s. 59, 76-81; Serdar Genç, Lale Devrinde Savaş, Iran Seferlerinde Organizasyon ve Lojistik (İstanbul: Kitap Yayınevi, 2013), s. 163-166.

73 Mühürdar Hasan Ağa, s. 383.

74 Abdurrahman Abdi Paşa, Vekâyi'-nâme, s. 282; Mühürdar Hasan Ağa, s. 382, 435; Mustafa b. Musa, Tarih-i Sefer ve Feth-i Kandiye, s. 111; Girid adasında olan Osmanlı ordusuna yardım için hatt-1 hümâyûn gereğince sipahilik şartıyla tahrir olunan serdengeçtilere ait bir defterde 1 kethüda, 1 başçavuş, 7 çavuş ve her bölükte bir yüzbaşı olmak üzere 100 civarı neferden müteşekkil 10 bölük, toplamda 1021 nefer serdengeçti kaydedilmiştir. 5 Z. 1078/17 Mayıs 1668 (BOA, Babı Defteri-Süvari Mukabelesi Kalemi Defterleri (D.SVM.d.), 36095, s. 2-6).

75 Mühürdar Hasan Ağa, s. 339, 341, 383, 413-414; Mustafa b. Musa, Tarih-i Sefer ve Feth-i Kandiye, s. 108-109.

76 Mustafa b. Musa, Tarih-i Sefer ve Feth-i Kandiye, s. 113.

77 Hikâyet-i Azimet-i Sefer-i Kandiye, s. 75. 
vermektedir. ${ }^{78}$ Yeniçeri ve cebeci gibi farklı ocaklardan askerlerin de bu muhasarada serdengeçti olarak bulunduğu göz önüne alınacak olursa oldukça yüksek sayıda kaybın verildiği ortaya çıkmaktadır. ${ }^{79}$

Osmanlılar kuşatmanın başarıya ulaşması için askerin motivasyonu kadar istihbarat faaliyetlerine de önem veriyorlardı. Bu da kale-kentin ahvalinden haberdar olmayı gerektiriyordu. Bunun için özellikle kaleden kaçarak Osmanlı ordusuna gelen firari kişiler ile ele geçirilen esirlerden alınan bilgiler önemliydi. Esirler konuşturulup bilgi alınmak için sadrazamın huzuruna getirilirdi ve bu istihbari işlevleri dolayısıyla dil/diller olarak tesmiye olunurlard $1 .{ }^{80}$ İlaveten kuşatma boyunca orduya kaleden firar edenler geliyordu. Metris alanında sadrazamın sekbanları yanında bu kişilere yer tayin edildiği gibi çadır mehterbaşısı da bunlara elbise dikmekle görevlendirilmişti. Firarilere ihsanlarda bulunuluyor; adadan ayrılmak isteyenler de donanmayla gönderiliyordu. Ayrıca içlerinden müslüman olanlar belirlenen metrislerde Osmanlı saflarına katılıyordu ${ }^{81}$ Ancak sadece esir ve firarilerden edinilen bilgilerle yetinilmeyerek kale içine bir şekilde casuslar da sokuluyordu. Casuslar elde ettikleri istihbaratı kağıtlara yazıp sapan taşlarına sarıyor ve bunları surların dışında önceden belirlenmiş bir mahale fırlatıyorlardı. Bu mahalde üç-dört nefer karavulcu sürekli atılan kağıtları toplamakla görevlendirilmişti. $^{82}$

Kuşatmanın ikinci yılında çatışmalar kalenin ana tabyaları ve önlerindeki hendek civarında yoğunlaşarak devam etti. Zaman ilerledikçe askerin iaşe sorunu tekrar ortaya çıktı. ${ }^{83} \mathrm{Et}$, pirinç ve yağ gibi gerekli yiyecek ürünleri ordu içinde azaldığından çok yüksek fiyatlara satılmaya başlamıştı. Özellikle ekmek bulmakta zorluk yaşanıyordu. Öyle ki sabah vakti fırınların önünde ekmek sırasında birkaç

78 Evliya Çelebi, Evliyâ Çelebi Seyahatnâmesi, 8. Kitap, s. 217.

79 Mühürdar Hasan Ağa, s. 365-366, 446-447; "her gürûhun kendüleri ve serdengeçdileri sıçan yolları üzere yürümede” (Mustafa b. Musa, s. 126).

80 Evliya Çelebi, Evliyâ Çelebi Seyahatnâmesi, 8. Kitap, s. 197-198; Mühürdar Hasan Ağa, s. 376, 450-451; Mustafa b. Musa, Tarih-i Sefer ve Feth-i Kandiye, s. 132.

81 Mühürdar Hasan Ağa, s. 329, 336-337, 340-341, 343, 345, 356, 358; Hikâyet-i Azimet-i Sefer-i Kandiye, s. 14; Evliya Çelebi, Evliyâ Çelebi Seyahatnâmesi, 8. Kitap, s. 189; Mustafa b. Musa, Tarih-i Sefer ve Feth-i Kandiye, s. 116-118; Kaleden firar eden bazı kişilere 1669 yılında verilen ihsanlar için bkz. BOA, İE.HLT., 1/92, s. 1, 3.

82 Hikâyet-i Azimet-i Sefer-i Kandiye, s. 44.

83 Sadrazam padişaha gönderdiği bir telhiste hicri 1079 (1668-69) yılı için Kandiye muhasarasındaki askerin zahireye "ziyâde" ihtiyaç duyduğunu vurgular (BOA, MAD., 4408, s. $5 / 1)$. 
bin adamın beklediği kuyruklar oluşuyordu. ${ }^{84}$ Aynı şekilde muhasara süresinin uzaması savaş malzemesini de olumsuz etkiledi. Ateşli silahların kullanılabilmesi için gerekli temel madde olan barut bir ara tükenecek noktaya geldi. Sadrazam ve defterdar askerin mücadele azmini etkilememesi için bu durumu gizliyorlardı. Fakat askerin huzursuzluğu her geçen gün artarak devam etti. Bir ara barutun ancak on günlük kaldığını öğrendiklerinde akılları başlarından gidecek noktaya geldi. Nihayet yardım donanmasının geldiğini haber aldıklarında rahatladılar. ${ }^{85}$

Donanmanın getirdiği iaşe ve sair levazımatın Kandiye önlerine ulaştırılması büyük problemdi. Kandiye çevresinde devriye gezen Venedik donanması yüzünden kale civarına yanaşılamıyordu. Bu nedenle yardım gemileri her geldiğinde olabilecek en yakın iskeleye yükü boşaltıyordu. $\mathrm{O}$ sırada devlet elinde hazır olan deve, katır gibi hayvanlar malzemenin taşınması için donanmanın yükü indirdiği iskeleye gönderiliyordu. Fakat çoğu zaman bu yük hayvanları yetersiz kaldığından çıkarılan bir fermanla ordu içinde her gruba gelen iaşe ve malzemenin taşınması için emir verilmişti. Kendi hayvanı olanlar üzerlerine düşen miktarı getirip bu vazifeyi yaptıklarına dair bir belge almışlar (temessük), hayvanı olmayanlar, kiralık yük hayvanı bularak bu vazifelerini tamamlamaya çalışmışlardı. ${ }^{86}$ Evliya Çelebi, ordu içinde kırk yerde kiralık eşek pazarı bulunduğunu ve bu tür zamanlarda çok iş yaptığını ifade eder. Hatta Girit reayasının bile eşeklerini kira pazarlarına getirip zikredilen işler için ücret karşıllı̆̆ kiraya verdiklerini vurgular. ${ }^{87}$

1668 yılının Ekim ayı sonlarında kapıkulu askerlerine metrislerde iki dönemlik maaşları dağıtılırken, altı aylık dönemde dört bin yeniçerinin çeşitli nedenlerle öldüğü mahlûlât defterine kaydedilmiştir. İki mevâcib süresince sadece yeniçeri ölümlerine dair verilen bu rakam diğer askeri gruplardan da çok sayida kayıp verildiğine güçlü bir işarettir. ${ }^{88}$ Aslında metriste bulunan bir asker için ölüm işin doğasında mevcuttu ve her yerden gelebilirdi. Müdafilerin attıkları

84 Mustafa b. Musa, Tarih-i Sefer ve Feth-i Kandiye, s. 114.

85 Mühürdar Hasan Ağa, s. 417. 1668-1669 döneminde Osmanlı Devleti, o yıl temin edilen güherçilenin büyük kısmına denk gelecek şekilde 7713,6 kantar rafine güherçile satın almıştı. Ayrıca, Kandiye kuşatmasında ateşli silahların kullanımı ve lağımların patlatılması için yüksek düzeyde barut ihtiyacı bulunduğundan, ülkenin çeşitli noktalarındaki baruthanelere ilave olarak Girit Adası'nda Hanya'da bir baruthane de kurulmuştu (Gabor Agoston, Barut, Top ve Tüfek: Osmanlı Imparatorluğu’nun Askeri Gücü ve Silah Sanayisi, Tanju Akad (çev.) (İstanbul: Kitap Yayınevi, 2006), s. 171, 199.

86 Mustafa b. Musa, Tarih-i Sefer ve Feth-i Kandiye, s. 114.

87 Evliya Çelebi, Evliyâ Çelebi Seyahatnâmesi, 8. Kitap, s. 180.

88 Mühürdar Hasan Ağa, s. 418. 
top güllelerine, tüfek kurşunlarına, humbaralara veya oklara hedef olabilirdi. Bir lağım saldırısında toprak altında kalabilir, atılan lağımlar sonucu saçılan serpinti taşlar çarpabilir ya da püskürme lağımın hedefi olup iki minare boyu havalanan veya altı metris uzağa firlayan bedeni cansız şekilde yere düşebilirdi. Yine bir püskürme lağım saldırısında havaya firlayıp denize düşebilir, ölü bedeni su üstünde kendini gösterebilirdi. Bunların da ötesinde uzun süre yaşamak zorunda olduğu toprak hendeklerin içinde türlü hastalıklara yakalanabilirdi. Söylenilenlerin tamamı ve daha fazlası Kandiye önlerinde sıklıkla görüldü. ${ }^{89}$ Hatta bazen ölümler o kadar çok oluyordu ki bazı yeniçeri odalarının neredeyse tamamı tek seferde kaybedilebiliyordu. Bu tür olağanüstü durumlarda bir günlük yeniçeri olmuş kişiler kendini aniden odabaşı olarak bulabiliyordu. ${ }^{90}$

Uzun süreli muhasara savaşlarında ölümler sadece asker kaybı anlamına gelmiyor, başka bir tehlike daha barındırıyordu. Mevtaların cesetleri bekledikçe hastalıklara davetiye çıkaracağından, bunların düzgün şekilde gömülmeleri gerekiyordu. Kandiye kuşatmasında Osmanlılar şehit olan askerlerin cesetlerini kilimlere koyup sıçan yolları vasıtasıyla taşıyarak metrislerin geri bölgelerinde hazırladıkları mezarlıklara gömdüler. Çok sayıda mevtanın olduğu zamanlarda askerler elbiseleriyle gömüldüler. Ancak imkân dâhilinde bazı durumlarda defin öncesi mevtalar gasilhanelerde yıkanıyordu. Hatta bazılarını bizzat Evliya Çelebi yıkamıştı. Böylece her gün ölen çok sayıda asker bekletilmeksizin belirlenen mezarlıklara defnedildi. Muhasaranın uzun sürmesi ölü sayısını artırdığından mezarlıkların sayısı da o oranda arttı. Bu yüzden bir zaman sonra ordu içinde mezarlıktan geçilmez oldu. Buna rağmen mezarlıklar savaş esnasında ölen tüm askerleri içermiyordu. Zira Kandiye kuşatmasında bir asker için cesedinin bulunup defnedilerek bir mezar taşına sahip olması bile neredeyse bir ayrıcalıktı. Özellikle lağım saldırılarında toprak altında kalan birçok asker, cesedine ulaşılamadığından çıkarılamadı. Evliya Çelebi kuşatma bittiğinde kırk elli yerde büyük mezarlık alanı olduğunu ve hayvanattan korumak amaciyla bunların etrafına hendek kazıldığını belirtir. İlaveten metris bölgesi düzleştirildiğinde altında cesetleri bulunamayan askerlerin varlığından bahseder. ${ }^{91}$

Muhasaranın ikinci yılının Kasım ayı geldiğinde padişah tarafından yeni bir hattı şerif sadrazama ulaştı. Padişah IV. Mehmet, savaşın üçüncü seneye uzaması

89 Mühürdar Hasan Ağa, s. 336-337, 342-345, 351, 356-357, 360, 383, 410, 416, 418, 441, 447.

90 Evliya Çelebi, Evliyâ Çelebi Seyahatnâmesi, 8. Kitap, s. 217.

91 Evliya Çelebi, Evliyâ Çelebi Seyahatnâmesi, 8. Kitap, s. 180, 182, 186, 188-191, 213. 
durumunda kuşatma ordusuna destek için asker, cephane ve sair malzemenin artık yeteri kadar temin edilmesi hususunda ciddi sorunlar yaşanacağını ifade ederek, rikâb-1 hümayuna gelmekte olan Venedik elçisine nasıl bir cevap vereceğine dair sadrazamdan görüş istedi. Padişahın üstü kapalı şekilde muhasaranın daha fazla sürdürülmesine şüpheli yaklaşımını anlayan Fazıl Ahmet Paşa, yanında bulunan mühürdarının nakline göre, o kadar huzursuz oldu ki üç gün üç gece ağladı. İki yıldır verilen büyük emeklerin boşa çımaması adına Kandiye kuşatmasına devam etmek istiyordu. Padişaha cevaben yazılan telhiste muhasaranın zor safhasının geçildiğini vurguladı ve hem askerin yorgunluğundan hem de özellikle lağım kazmak için beldar eksikliğinden dem vurdu. Ayrıca daha sonra gönderdiği bir başka telhiste asker ve barut ihtiyacından bahsetti. Bunların giderilmesiyle fethin çok yakın olduğunu bildirdi. Nihayetinde amacına ulaşan sadrazam, padişahı ikna etti ve Kandiye önlerindeki Osmanlı ordusu ikinci kışını metrislerde geçirmek için önceki yıla benzer hazırlıklara başladı. ${ }^{92}$

Metrislerde geçirilen ikinci kış da bir öncekini aratmayan zorluklarla geçti. ${ }^{93}$ Müdafilerin giriştikleri büyük bir huruç harekâtını güçlükle karşılayan Osmanlı askerleri ciddi sayıda kayıp verdi. Kayalık alan içinde binbir zahmetle hazırlanan lağımlar aşırı yağışlar sonucu suyla dolduğundan kullanılamaz hale gelmişti. Askerler kırba, gerdel ve tulumbalarla bu suları tahliye ettikten sonra, yakın noktalardaki müdafi lağımlarını iptal etmek için lağımlara barut doldurup havaya uçurdular. ${ }^{94}$ Bütün bir kış bu şekilde yer üstünde ve altında savaşarak geçerken ${ }^{95}$ Ocak ayında bir Venedik elçisinin Hanya limanına geldiği haberi ordu içinde yayıldı. Yaklaşık iki yıldır yaşadıkları metrislerde oldukça bunalan askerler bir an önce bu işin sonlanmasını arzu ettiklerinden hemen heyecana kapıldılar ve elçinin kaleyi teslim için geldiği zannına kapılarak sabaha kadar sevinç içinde adeta bayram ettiler. Ancak kısa bir müddet sonra Venedik elçisinin hapsedilmesi amacıyla padişah

92 Mühürdar Hasan Ağa, s. 419-421. Seyyah Chardin, uzayan muhasara yüzünden sadrazamın düştüğü zor durumu anlatırken, Osmanlı toplumunda Kandiye kuşatmasına dair var olan bir düşünceyi şöyle özetler: "Bütün Türkler savaştan yakınıyorlar, gereksiz bir körlükten dolayı bütün Osmanlı güçlerinin bir kayaya saldırtılarak yok edileceğini söylüyorlardı”, Chardin, Chardin Seyahatnamesi, s. 81-82.

93 Mustafa b. Musa, Tarih-i Sefer ve Feth-i Kandiye, s. 117; Defterdar Sarı Mehmed Paşa, Zübde-i Vekayiât, Tablil ve Metin (1066-1116/1656-1704), Abdülkadir Özcan (haz.) (Ankara: Türk Tarih Kurumu, 1995), s. 13-14.

94 Mühürdar Hasan Ağa, s. 421-423; Boyraz, Köprülüzâde Fazıl Ahmet Paşa Devrinde (10691080) Vukuatı Tarihi, vr. 62b.

95 Evliya Çelebi, Evliyâ Çelebi Seyahatnâmesi, 8. Kitap, s. 190-191. 
tarafından Hanyàya gönderildiği anlaşıldığında mutluluk emareleri yerini derin bir üzüntüye bıraktı. Olayın müşahitlerinden Hasan Ağa, ordunun iki üç saat gibi çok kısa bir zaman dilimi içinde sevinç ve keder gibi iki zıt duyguyu yoğun şekilde yaşamasının bıkkınlığa yol açtığını ve kimsede can kalmadığını dile getirir. Çok geçmeden rikâb-1 hümayundan gelen hatt-1 şerif ve hediyeler adeta Hızır gibi yetişti. Padişah tarafından gönderilen hilatler, humbaracı ve lağımcıbaşılar dâhil çok sayıda kişiye giydirildi. Ayrıca okunan hatt-1 şerifte gerekli asker ve mühimmatın peyderpey gönderildiği müjdelenmişti. ${ }^{96}$

1669 yılı başları kalenin ana tabyaları ile diplerindeki büyük hendeklerde karşılıklı mücadelelerle geçti. Kalenin ana tabyaları oldukça geniş ve toprak dolguya sahip olduğundan Osmanlılar bu engeli aşmak için tabyaların topraklarını torbalarla taşıyarak tabyaları zayıflatmaya çabalıyorlardı. ${ }^{97}$ Ancak, esas mücadele yine yer alında yaşanıyordu. Kaynakların ifadesiyle lağım cengi başka bir cenge benzemiyordu. Hiç beklenmedik anda atılan lağımlar hatırı sayılır zararlar veriyordu. Nitekim ilkbaharda müdafiler yaptıkları lağım saldırısıyla bir top tabyasını dağıttılar. Yine başka bir saldırıda Defterdar Paşa Tabyası olarak anılan büyük bir tabya lağımın hedefi oldu. Oldukça muhkem bina edilmiş olan tabya, askerlerin tüfekleriyle konuşlanacağ 1 iki kata sahipti ve üzeri de çeşitli nesnelerle örtülmüsstü. Lağımın atıldığı esnada üzerinde bulunan yirmi otuz kadar askerin bir kısmı öldü ve bir kısmı da yaralandı. Ölüler arasında sadrazamın çok sevdiği hizmetkârı olan mehterbaşı da vardı. Muhasara boyunca yaptığı hizmetler ve gösterdiği gayretle cümle metris halkının hayran olduğu bu kişinin ölümüne sadrazam çok üzüldü ve uzun süre ağladı ${ }^{98}$ Aslında sadrazamın bu mehterbaşısı gibi daha birçok kişi verdikleri üstün mücadeleler sonucu ordu içinde hatırı sayılır bir üne kavuşuyordu. En zor ve tehlikeli görevleri korkusuzca yerine getiren bu kişilere asker arasında saygıyla bakılıyor, sergiledikleri yiğitlikleri imrenilerek dilden dile dolaşıyordu. Kandiye kuşatmasında Kanca Dilâver ${ }^{99}$ ve yaptığı çatışmayla destanlaşan Bolpaça bunlar arasında öne çıkanlardı. ${ }^{100}$

Kuşatmanın üçüncü yılında muharebenin çok şiddetlendiği anlar vuku bulmaya başladı. Top gülleleri, tüfek daneleri, havan humbaraları ve taşları askerlerin

96 Mühürdar Hasan Ağa, s. 423-426.

97 Mühürdar Hasan Ağa, s. 423.

98 Mühürdar Hasan Ağa, s. 434-435, 438.

99 Kanca Dilâver ve oğlunun hayli ilgi çekici hikâyesi için bkz. Pul, Girit Savaşı İle İlgili Bir

Türk Kaynă̆ının Tahlili, s. 167-172.

100 Mühürdar Hasan Ağa, s. 312-313, 328, 344; Hikâyet-i Azimet-i Sefer-i Kandiye, s. 14-15. 
üzerine yağmur misali yağarken bu ateşli silahların çıkardıkları sesler ortalığı kaplıyor, yer gök 'şiddeti sadâdan' titriyordu. Barut dumanı gökyüzünü kapladığında gündüzleri en karanlık gecelere benzetiyordu. Ardı arkası kesilmeyen lağım saldırıları depremi andıran yer sarsıntılarına yol açıyor, atılan humbaralardan bazıları denize düştüğünde, dipteki balıkların cansız bedenleri karaya vuruyordu. ${ }^{101}$

Her türlü çatışmaya rağmen dini bayramların geldiği zamanlar ordugâhta hava birden değişirdi. 1669 yılının 11 Mayıs Cumartesi gününe denk gelen Kurban Bayramı'nda da öyle oldu. Üç kez yapılan top atışı Osmanlı ordusuna bayramı müjdelerken aynı zamanda müdafilere de mesaj veriyordu. Her birlik kendi içinde bayramlaşıyordu. Kısa bir müddet de olsa sanki savaş unutulmuş gibiydi. Yeniçeriler, her yıl mutat olarak kendilerine verilen Selanik çuhasından imal ettirdikleri yeni kabanlarını giymişlerdi. Herkes birbirine hediye veriyordu. Mesela, bir asker arkadaşına tütün, arkadaşı da ona kahve ikram ediyordu. Komutanlar ise veziriazama hediye gönderiyor ve yine bir hediye ile mukabele görüyorlardı. Ordu içinde değnek cezası alan askerler bayramın hürmetine affedilmişti. Bayram günlerinde ihsanların arttığının farkında olan kimi yeniçeriler, o gün daha fazla akçe almak için, üç dört gün sakladıkları müdafi kellelerini gizledikleri yerden çıkarmışlardı. Böylece kutlamalar gün boyu devam ettti. ${ }^{102}$

Muhasara esnasında bayramlar her ne kadar yüzlerde bir tebessüme vesile olsa da hayli meşakkatli büyük bir mücadele içinde çok küçük bir yer işgal ediyordu. Nitekim kısa bir süre sonra her şey tekrar eskisine döndü ve askerler savaşın zorluklarıyla yeniden yüzleştiler. Özellikle lağım saldırıları büyük kayıplara sebep olmaya devam ediyordu. Askerler bir yandan arkadaşlarını toprak altından çıkarmaya çalışıyor, diğer yandan sıçan yollarını tıkayan taş ve toprağı temizliyordu. Tüm bunlar yapılırken müdafilerin saldırıları da mütemadiyen devam ediyordu. Muhasaranın üçüncü yılının bu tür sıkıntılı zamanları neferlerin zihinlerinde şöyle kaygılı düşünceler oluşturuyordu:

"Acabâ nice olur hâl işte bu senede işimiz böyle olursa bu vechile kimesnede tâkat kalmadı ve yine eyyâm-ı şitâ girüb evvel-i bahâr irişdi, eger lutf-ı Hakk olursa donanmamız ile birkaç bin cedìd askerimiz ve cebehânemiz ve zahiremiz gelüb ve sâyir erbâb-ı ze'âmetin ve erbâb-ı tımârın dahi ola ki harclıkcıları gelüb, imdâd iderlerse belki bu senede güz eyyamina değin sabır ve tahammül olur ola, bu sene bâri üçüncü

101 Mühürdar Hasan Ağa, s. 440.

102 De la Guillatiere, An Account of a Late Voyage to Athens, s. 391-395. 
seneye karîb oldı. Bu kal'a cengi ümîddir ki cenâb-ı Allahh lutf-ı kereminden fethin mukadder etmis olaydr. ${ }^{103}$

Zaman ilerledikçe savaşın sıkıntılarına katlanmak gittikçe zorlaşmıştı. Birçok savaşa bedel olan muhasara, askerleri her geçen gün biraz daha yıpratmıştı. Usanç hali ordunun üzerine kara bir gölge gibi düşmüştü. Eğitim ve disiplin seviyeleri ne olursa olsun askerlerin bir dayanma eşiği vardı. Nitekim bazı gruplar kontrolü kaybederek mevzilerini terk etmek istediler. Osmanlı savaş yönetimi için isyan kapıdaydı. Bir grup sipahi serdengeçtisi başkaldırarak metristeki sadrazam tabyasına kadar geldiler. Savaşmak istemiyorlardı. Sadrazam önce konuşarak ikna etmeye çalıştı. Ancak birkaç gün sonra yeniden başkaldırdıklarında, yeniçeri ağası ve kul kethüdası önderliğinde ite kaka zorla metrislerine konuldular. Daha sonraları sıçan yolu yürütmeleri için ferman çıkarılan bir grup silahdar serdengeçtisi, görevlerini yapmak istemeyerek benzer bir kalkışmada bulundu. Hiçbir çözüm önerisini kabul etmeyince, metrisleri iki taraftan ihata edildi. Akıbetlerinin iyi olmayacağını anladıklarında hemen aman dilediler. Ordu içinde isyan en utanç verici hareketlerden biriydi. Ne kadar yaptıklarından pişman olup başlarını kurtarsalar da metris halkı içinde itibarlarını kaybetmekten kurtulamadılar. Öyle ki Mühürdar Hasan Ağa bu olayın sonucunda “cümle halk yüzlerine tükürdü” ifadesini kullanmıştır. ${ }^{104}$

İsyan eden gruplar ne kadar bastırılsa da kuşatma süresince firar eden askerlerin önüne geçilemedi. Kandiye muhasarası çok sayıda lağım açılmasını gerektirdiğinden o oranda beldar ve lağımcıya ihtiyaç vardı. Bu nedenle kuşatma öncesi ve süresince imparatorluğun çeşitli yerlerinden önemli miktarda beldar ve lağımcı adaya gönderilmişti. ${ }^{105}$ Ancak savaşın uzaması ve karşılaşılan güçlükler had safhaya vardığında bazı neferler mücadeleden vazgeçebiliyordu. Böyle zamanlarda askerler bir sabah uyandıklarında yanındaki arkadaşlarını metrislerde göremeyebiliyorlardı. Nitekim deftere yazılarak Girit'e sevk edilen beldarların bir kısmı yoklamalardan hemen sonra, bir kısmı da bir müddet metriste çalıştıktan sonra

103 Mustafa b. Musa, Tarih-i Sefer ve Feth-i Kandiye, s. 126.

104 Mühürdar Hasan Ağa, s. 436, 443-444.

105 Kandiye'nin son kuşatması için Anadolu'nun her on avarız hanesinden bir beldar olmak üzere toplam 3500 beldar yazılması ve 500 ücretli üstad lağımcı tutulmasına dair 19 Ca. 1078/6 Kasım 1667 tarihli telhis için bkz. BOA, YB.04., 2/87, s. 1; Cengiz Orhonlu, Osmanlı Imparatorluğu'nda Derbend Teşkilâtı (İstanbul: Eren Yayıncılık, 1990), s. 84; Gülsoy, Giritin Fethi, s. 211-217. 
firar etmişlerdi. ${ }^{106}$ Aynı şekilde lağımcılardan da kaçanlar olmuştu. ${ }^{107}$ İlaveten tımarlı sipahilerden firar edenler de vard. ${ }^{108}$

Osmanlı askerleri her şeye rağmen kalenin ana tabyalarına doğru saldırmaktan hiç geri durmadılar. Bazı tabyaların önemli bir kısmı da ele geçirildi. Ancak daha fazla ilerlemek için aşmak zorunda oldukları yeni bir engelle daha karşılaştılar. Müdafiler tabyaların iç kısımlarında yeni bir savunma hattı inşa etmiş; kerpiçten yapılmış duvarlar toprakla doldurularak üzerine tüfekli askerler ve toplar yerleştirmiş, bunların önleri ise şaranpolarla tahkim edilmişti. Yapılan bir harp divanı sonrasında lağım faaliyetlerinin aralıksız devam etmesine ve kuşatılan tabyalar üzerinde on kadar sıçan yolu yürütülerek yeni yapılan kerpiç duvarın aşılmasına karar verildi. Neticede her askeri grup tayin edildikleri tabyalarda belirlenen sayıda sıçan yolu kazarak kale içine doğru ilerlediler. ${ }^{109}$

Çatışmaların şiddetlendiği zamanlarda kayıplar da arttı. Örneğin 1669 yılının Temmuz ayında Rumeli kolunda atılan bir lağım sonucu yetmiş kadar asker öldü. Ayrıca muharebeler çok sayıda neferin yaralanmasına yol açtı. Rumeli Beylerbeyi Hüseyin Paşa da yaralananlar arasındaydı. Hemen kendi metrisinde bina edilmiş tabyasına getirildi. Cerrahlar gelerek yarasına müdahale ettiler. ${ }^{110}$ Aslında Kandiye kuşatması boyunca bir şekilde yara almayan asker yok gibiydi. Bu yüzden yaralıların hızlı şekilde tedavi edilmeleri gerekiyordu. Bunun için ordu içinde birçok hekim ve cerrah vardı. Evliya Çelebi Kandiye önlerinde yetmiş tane cerrah çadırı ile kırk tane hekim dükkânı ve çadırının bulunduğunu belirtir. Hekim ve

106 Kandiye kuşatmasının son devresinde çeşitli sancaklardan deftere kaydedilip ancak daha sonra firar eden 270 beldar için bkz. BOA, MAD., 15333, s. 1-8. Ancak bunlardan alınacak bedellerin toplamını gösteren sayfada kişi toplamı 269'dur (s. 10).

107 İzmir'den ücretle tutulan 50 lağımcıdan 13'ü adaya gitmeden, 3'ü ise Girit'e ulaştıktan sonra kaçmışlardı. İzmir kadısına gönderilen 11 Mart 1669 tarihli hükümde, kefillerinden bunların yerine yenilerinin tutularak adaya sevk edilmelerinin sağlanması emredilmişti. Gülsoy, Giritin Fethi, s. 213. Ayrıca, Kandiye kuşatmasının son devresinde firar eden 8 lağımc1 için bkz. MAD., 15333, s. 9.

108 Örneğin, Aydın sancağında tımar sahibi olan Ömer'in sefer sırasında Girit Adası'ndan firar etmesinden dolayı elindeki tımarı alınmıştı, 3 Ca. 1080/29 Eylül 1669 (BOA, İE.AS., 22/1970, s. 1).

109 Mühürdar Hasan Ağa, s. 441, 445-447; Mustafa b. Musa, Tarih-i Sefer ve Feth-i Kandiye, s. 125; Evliya Çelebi, Evliyâ Çelebi Seyahatnâmesi, 8. Kitap, s. 193; Defterdar Sarı Mehmed Paşa, Zübde-i Vekayiât, s. 14-15.

110 Mustafa b. Musa, Tarih-i Sefer ve Feth-i Kandiye, s. 127; Mühürdar Hasan Ağa, s. 452. 
cerrahlar metrislerin gerisinde yaralılara müdahale ediyorlardı. ${ }^{111}$ Tedavi için gerekli malzemeler muhasara boyunca tedarik ediliyordu. ${ }^{112}$ Tek seferde çok sayıda yaralının olduğu çatışmalar ile salgın hastalıkların ordu içinde yayıldığı zamanlar hekim ve cerrahların işleri iyice zorlaşıyordu. Yarası hafif olup tedavisi tamamlananlar yeniden mevzilerine dönerken, ağır yaralı olup savaşamayacak durumda olanlar donanma ile memleketlerine gönderiliyordu. ${ }^{113}$ Askerlere yaralanma düzeylerine göre bahşiş de veriliyordu. ${ }^{114}$ Ayrıca zaman zaman cerrahlar da inama mazhar olabilmekteydi. ${ }^{115}$

Uzayan muhasara metris bölgesini, sadece kaleyi ele geçirmek için gerekli mücadelenin yapıldığı bir savaş mevzisi olmaktan çıkarmış, hiyerarşik olarak en yüksek rütbelisinden basit bir nefere kadar askerler için bir yaşam alanına da dönüştürmüştü. Özellikle kış aylarını geçirmek için daha korunaklı olarak yapılan geri metris hatları, ev benzeri meskenlerle dolmuş, ayrıca zaman içinde inşa edilerek yapılan çarşı alanları ile birlikte metris alanı adeta bir şehre dönüşmüştü. Buradaki gündelik hayat bir bakış açısıyla oldukça rutindi ve bir görgü şahidinin ifadesine göre ateşli silahların çıkardığı sesler haricinde şaşırtıcı derecede sessizlik vard. ${ }^{116}$ Herkes kendisi için belirlenmiş muhasara kolunda bulunuyordu. Ön saflarda savaşan gruplar sıçan yollarını kullanarak kendi metrislerine gelip dinleniyor; ${ }^{117}$ yemeklerini yiyip kahvelerini yudumluyorlardı. Namazlar toplu veya bireysel olarak kılınabiliyordu. Toplu olarak yapılan görevlendirmeler, ordu içinde münadi ve tellallar vasıtasıyla duyuruluyor; hemen her gece, askerleri yeniden motive etmek için ertesi gün müdafilerden alınacak kellelere ödenecek ücretler ilan ediliyordu. Tabii bu türden bir gündelik yaşamda tehlike hiç

111 Evliya Çelebi, Evliyâ Çelebi Seyahatnâmesi, 8. Kitap, s. 180, 186, 190. 1667 senesi Kasım'ında Fazıl Ahmet Paşa, 16 cerrahın Girit'e gönderilmesi için sadaret kaymakamı ve defterdara hüküm yazmıştı. Gülsoy, Girițin Fethi, s. 211. Sonraki zamanlarda da hekimlerin getirildiği anlaşılmaktadır. Örneğin hekim Mersadi 1669 yılı yazında gelmişti. BOA, İbnüleminSihhiye (İE.SH.), 1/14, s. 1.

112 BOA, İE.SH., $1 / 45$, s. 1-4.

113 Mühürdar Hasan Ağa, s. 367.

114 Mustafa b. Musa, Tarih-i Sefer ve Feth-i Kandiye, s. 106.

115 BOA, İbnülemin-Maliye (İE.ML.), 23/2163, s. 1.

116 De la Guillatiere, An Account of a Late Voyage to Athens, s. 379-380, 385.

117 Siperlerin korunması için günlük olarak düzenlenen birlikler 12 saatte bir değiştiriliyorlardı. Eğer bir bölüğe tüm gün görev verilirse Çorbacı yarısını siperleri beklemeleri için alıyordu ve on iki saat sonra odabaşı bunları diğer yarıyla değiştiriyordu. De la Guillatiere, $A n$ Account of a Late Voyage to Athens, s. 382. 
eksik olmuyordu. Bir bayram günü askerler metriste sohbette iken ani bir huruç harekâtına maruz kalabiliyor; barınaklarda istirahat halinde bulunurlarken atılan top seslerinden huzurları kaçabiliyor; cemaatle kılınan bir namaz esnasında bir lağım saldııısı yeri titretebiliyor; atılan humbaralar namazını eda eden bir askerin seccadesinin önüne düşebiliyor, bir kahvecinin fincan sepetine isabet edebiliyor veya metriste su taşıyan sakaları yaralayabiliyordu. Metriste bulunan bir nefer için bunlar olağan şeylerdi. Çünkü savaş ve gündelik hayat iç içeydi. ${ }^{118}$

Kandiye kuşatması sırasında Osmanlı askerlerinin hayatına ışık tutması açısından, Evliya Çelebi'nin kendi yaptıklarına bakmak faydalı olabilir. Muhasara boyunca metrislerde bulunan Evliya Çelebi kuşatma süresince üç binden fazla ok ve çok sayıda kurşun attığını, çok sayıda toprak dolu torba taşıdığını, nerede bir top güllesi bulursa bunları taşıyarak topların yanına getirdiğini, şehit olan askerleri gasledip defnettiğini, yaralıları cerrahlara teslim ettiğini, onlara ekmek ve çorba getirdiğini, yine yaralıların bitlerini temizlemek için saç, sakal ve bıyıklarını kestiğini, onların elbiselerini yıkadığını, eski metriste bitap düşmüş kimselere kendi tulumbasıyla su taşıdığını ve her Cuma akşamı bir hatim indirdiğini dile getirir. ${ }^{119}$

Üçüncü yılın yaz aylarında zikredildiği üzere çok sayıda sıçan yolu kale içine doğru yürütülüyordu. Sadrazam kuşatmayı iyice yoğunlaştırmak için büyük gayret içindeydi. Kalenin doğu tarafındaki muhasara birliklerini desteklemek amacıyla Kaptanıderya Kaplan Mustafa Paşa emrindeki kuvvetlerle bu bölgede görevlendirildi. Böylece donanmayı bırakıp kuşatmada muharip unsur olarak belirlenen noktaya hareket eden Kaptanıderya vakit geçirmeden Osmanlı taarruzlarına katıldı. ${ }^{120}$

Kuşatmanın giderek şiddetlendiği bir zamanda, Fransız askerlerin öncülük ettiği bir müttefik kuvveti Kandiye’ye yardım maksadıyla gelerek kaleye dâhil oldu. ${ }^{121}$ Bu yardım kuvveti kısa bir süre sonra büyük bir huruç harekâtında bulunsa da başarılı olamayarak geri çekilmek zorunda kaldı (25 Haziran 1669). Bu huruç esnasında metris alanında yer altında bulunan bir Osmanlı barut deposunun atılan el humbarası ile havaya uçması çok sayıda müdafinin ölmesine sebep oldu ve başarıda önem-

118 Mühürdar Hasan Ağa, s. 330, 333-334, 337, 417, 441-442; Hikâyet-i Azimet-i Sefer-i Kandiye, s. 29; Evliya Çelebi, s. 181-182, 192, 203; De la Guillatiere, An Account of a Late Voyage to Athens, s. 379-380, 382-383, 399.

119 Evliya Çelebi, Evliyâ Çelebi Seyahatnâmesi, 8. Kitap, s. 187-188.

120 Mustafa b. Musa, Tarih-i Sefer ve Feth-i Kandiye, s. 128; Mühürdar Hasan Ağa, s. 448.

121 Müttefik yardım birliğinin sayısı ve gemileri gibi detaylar için bkz. Nuri Adıyeke, "Girit Savaşları ve Birleşik Hıristiyan Orduları”, Türkler, c. IX, (Ankara: Yeni Türkiye Yayınları, 2014), s. 742-743. 
li rol oynadı. ${ }^{122}$ Yaklaşık bir ay sonra son bir hamle olarak, müttefik donanması denizden Osmanlı metrislerini durmaksızın top ateşine tuttu. Buna kaledeki toplar da katıldı. Öyle ki metrislerde top gürültüsünden kimse birbirini duyamaz hale gelmişti. Metris alanına düşen top gülleleri o kadar çoktu ki kaynakların ifadesiyle ortalık adeta bir karpuz bostanına dönmüştü. ${ }^{123} \mathrm{Hep}$ birden başlayan bombardıman Osmanlı askerlerini metrislerden söküp atmayı hedefliyordu; fakat yaklaşı üç saat süren mücadele birçok müttefik gemisinin zarar görmesine ve neticede Ağustos ayı sonlarında geri çekilmesine neden oldu. Kısa bir zaman sonra ilerleyen sıçan yolları yeni savunma hattını yararak kale içine çok yaklaştı. Tam bu sırada müdafiler büyük çabalarla savundukları Kandiye’nin daha fazla dayanamayacağını gördüklerinden kaleyi anlaşma yoluyla teslim etmeye karar verdiler. ${ }^{124}$

Teslim görüşmeleri neticelenip kalenin boşaltılmasını beklerken kalenin bir tarafında aniden cenk bayrağı gören Osmanlı askerleri, hemen mevzi alıp durumu sadrazama bildirdiler. Tam her şey bitmiş, çekilen çileler emeline ulaşmış derken yeniden savaş kapıda mıdı? Endişe yaratan bu durum zihinleri derinden sarsıyor askerler, yaklaşık iki buçuk yıldır toprak içinde metrislerde adeta kabir azabına benzeyen mücadele dolu yaşamlarına bakıyor ve "Yâ Rabbî bu ne belâ-yı azîm olur?” diyerek kederleniyorlardı. Ancak çok geçmeden yüreklere su serpen müjdeli haber geldi ve kalenin tesliminde bir sorun olmadığını öğrendiler. Neticede kalenin anahtarları Eylül 1669 'da Sadrazam Fazıl Ahmet Paşàya teslim edildi. ${ }^{125}$

Kandiye ele geçirildikten sonra, büyük bedeller ödenen bu zafer için günlerce sürecek kutlamalar yapıldı. ${ }^{126}$ Geceleri havai fişekler atılıp, mumlar, kandiller yakıldı. Atılan top ve tüfek sesleri zafer naralarına karışırken, olası bir saldırıda düşman

122 Mustafa b. Musa, Tarih-i Sefer ve Feth-i Kandiye, s. 131-132; Boyraz, Köprülüzâde Fazıl Ahmet Paşa Devrinde (1069-1080) Vukuatı Tarihi, vr. 70a; Zinkeisen, Osmanlı Imparatorluğu Tarihi (1623-1669), c. 4, s. 695-696.

123 Müttefik yardım donanması Osmanlı metrislerine 12 ila15 bin top güllesi atmıştı (Setton, Venice, Austria and the Turks, s. 226.)

124 Mustafa b. Musa, Tarih-i Sefer ve Feth-i Kandiye, s. 129-136; Mühürdar Hasan Ağa, s. 450-456; Boyraz, Köprülüzâde Fazıl Ahmet Paşa Devrinde (1069-1080) Vukuatı Tarihi, vr. 72a; Fahri Oluk, "Camiü'd-Düvel, Sultan IV. Mehmet Dönemi Tercüme, Metin ve Değerlendirme” (Yayımlanmamış Doktora Tezi, Erciyes Üniversitesi Sosyal Bilimler Enstitüsü, 2011), s. 104-105; Setton, Venice, Austria and the Turks, s. 225-229.

125 Evliya Çelebi, Evliyâ Çelebi Seyahatnâmesi, 8. Kitap, s. 206-208; Mühürdar Hasan Ağa, s. 459-461.

126 Mühürdar Hasan Ağa, s. 462; Hikâyet-i Azimet-i Sefer-i Kandiye, s. 58; Evliya Çelebi, Evliyâ Çelebi Seyahatnâmesi, 8. Kitap, s. 209-210. 
tarafından kullanılmaması için bin bir zahmet çekip büyük bedeller ödeyerek hazırladıkları, kışın yağışları altında, yazın bunaltıcı sıcağında yıllarca yaşadıkları, hülasa taş yasdanup toprak döşendikleri metrisleri doldurmak yine cümle askere kalıyordu. ${ }^{127}$

\section{Sonuç}

Osmanlıların Girit Adası'na düzenledikleri sefer, özellikle Kandiye Kalesi yüzünden yirmi yılı aşkın bir süre devam etmiştir. Kandiye muhasarasının Sadrazam Fazıl Ahmet Paşa komutasındaki son devresi ise eşine az rastlanır bir çatışma sürecine dönüşmüştür. Kale önünde hazırlanan metris ve sıçan yolları vasıtasıyla kademe kademe surlara yaklaşan askerler, kalenin teslimine kadar yaklaşı iki buçuk yıl büyük bir mücadele azmi göstermişlerdir. Muhasaranın bu son devresi, hemen bir kuşatma savaşında görülebilecek tüm olaylara sahne olması ve özellikle metrislerde yapılan meskenlerde askerlerin hayatlarını idame ettirmesi gibi birçok yönden oldukça dikkat çekicidir.

Metris alanının oluşturulması sırasında Osmanlıların karşılaştıkları engeller onları yeni taktikler uygulamaya sevk etmiştir. Lağımları sadece kaleye bir saldırı yöntemi olarak tatbik etmek yerine, metrisler kale surlarına yaklaştırılırken yer altı emniyetinin sağlanması için de kullanmışlardır. İki kış mevsimini metrislerde geçirmek zorunda kalan askerler, metris ve sıçan yollarının içlerine çeşitli şekillerde barınaklar inşa etmişlerdir. Buralarda zamanla alış-veriş alanları oluşturulduğu gibi ölen askerlerin gömüldüğü mezarlıklar da kendine yer bulmuştur.

Savaşa tanık olmuş kişilerin anlatıları, bu muhasarada askerlerin metris bölgesindeki yaşamını aydınlatacak veriler sunmaktadır. Osmanlı askerlerinin bir kale kuşatması sırasında metris alanını nasıl oluşturdukları, gündelik hayatlarını nasıl geçirdikleri, ihtiyaçlarını nasıl giderdikleri, ibadetlerini nasıl yaptıkları, dini bayramlarını nasıl kutladıkları gibi nispeten geri planda kalmış birçok konuya bu incelemeyle ışık tutulmaya çalışılmışır. Ayrıca askerlerin uzun süren muhasara savaşlarında yaşadıkları psikolojik baskılar ve bunlara karşı dayanma eşikleri de biraz daha belirginleştirilmiştir. Tüm bunlara ilaveten, Osmanlılar açısından Kandiye muhasarasının 1667-1669 döneminde, müdafilerin savunma çabaları kadar lojistik desteğin, iklimin, hastalıkların, askeri motivasyonun ve ordu içi isyanların da kuşatmaya etki ettiği tespit edilmiştir.

127 Mustafa b. Musa, Tarih-i Sefer ve Feth-i Kandiye, s. 141; Evliya Çelebi, Evliyâ Çelebi Seyahatnâmesi, 8. Kitap, s. 213. 
Taş Yasdanup Toprak Dössenenler: Kandiye Kuşatması Örneğinde Osmanlı Askerlerinin Metristeki Mücadele ve Yaşamı (1667-1669)

Öz - Osmanlı askeri tarihinde önemli bir yekûn tutan kale kuşatmalarının meydan muharebelerine nazaran çok daha uzun sürelere yayıldığı görülmektedir. Osman$l_{1}$ tarihi incelendiğinde haftaları, ayları ve hatta yılları aşan kuşatmalara rastlamak mümkündür. Bu uzun süreçler salt savaşırken verilen mücadeleyi değil, en az onun kadar zorlu geçen açlık, hastalık, zor iklim koşulları ve uzayan muhasaranın oluşturduğu psikolojik problemleri de içeren bir mücadeleyi kapsamaktadır. Bu yönüyle kale kuşatmasında bulunan askerlerin karşısında, müdafiler dışında aşmak zorunda oldukları bir dizi engel daha bulunmaktadır. Bu çalışmada Kandiye (1667-1669) kuşatması örneğinden yola çıkarak muhasaralarda Osmanlı askerlerinin metristeki maddi ve manevi yaşamı ile muhasara sırasındaki mücadele sürecine odaklanılacaktır.

Kandiye muhasarasında askerler yaklaşık iki buçuk yılı içine meskenler inşa ettikleri metrislerde geçirmişlerdir. Metris bölgesinin geri hatlarındaki hendekleri çeşitli dükkânlarla dolu bir çarşıya dönüştürmüşlerdir. Bu metrisler kale müdafilerinin top, tüfek ve humbara atışları ile lağım saldırılarından korunmaya çalıştıkları bir mücadele alanı olduğu gibi aynı zamanda dinlendikleri, yemeklerini yedikleri, ibadetlerini yaptıkları mekânlara dönüşmüştür. Ancak zaman içinde sorunlara yenileri eklenmiştir. Aşırı yağışlar gibi zor iklim koşullarına maruz kalmışlar, sağlıkları salgın hastalıklarla tehdit altına girmiş ve hatta bu sebeplerle hayatlarını kaybetmişlerdir. Kandiye Kalesi kuşatmasında askerler bu katlanması güç sorunlara göğüs germişler ve kuşatmaya uzun süre devam etmişlerdir.

Anahtar kelimeler: Girit, Kandiye Kalesi, Kuşatma, Osmanlı askerleri, Metris, Köprülü Fazıl Ahmet Paşa

\section{Bibliyografya}

\section{Arşiv Kaynakları}

Başbakanlık Osmanlı Arşivi (BOA)

BOA, Bab-1 Defteri Süvari Mukabelesi Kalemi Defterleri (D.SVM.d.): nr. 36095.

BOA, İbnülemin Askeriye (İE.AS.), 22/1970.

BOA, İbnülemin Hil'at (İE.HLT.), 1/92, 1/93.

BOA, İbnülemin Maliye (İE.ML.), 23/2163.

BOA, İbnülemin Sıhhiye (İE.SH.), 1/14, 1/45.

BOA, Maliyeden Müdevver Defterler (MAD.), 4026, 4408, 15333.

BOA, Yabancı Arşivler-Bulgaristan Arşivi (YB.04.), 2/85, 2/86, 2/87, 2/88.

\section{Bibliothèque Nationale de France}

Département Cartes et Plans, GE D, nr. 13624; GE DD, nr. 2987 (6312), 2987 (6313). 


\section{Yayınlanmış Eserler}

Abdurrahman Abdi Paşa: Vekâyi'-nâme [Osmanl Târihi (1648-1682)], Tahlil ve Metin Tenkidi, haz. Fahri Çetin Derin, İstanbul: Çamlıca Basım Yayın 2008.

Adıyeke, Nuri: "Girit Savaşları ve Birleşik Hıristiyan Orduları”, Türkler, c. IX(Ankara: Yeni Türkiye Yayınları 2014), s. 738-745.

Adıyeke, Nuri: "Hikâyet-i Azimet-i Sefer-i Kandiye”, (Yayımlanmamış Yüksek Lisans Tezi) İzmir: Ege Üniversitesi, Sosyal Bilimler Enstitüsü, 1988.

Agoston, Gabor: “Avrupada Osmanlı Savaşları: 1453-1826”, Osmanlida Savaş ve Serhad, çev. Kahraman Şakul, İstanbul: Timaş Yayınları, 2013, s. 79-109.

Agoston, Gabor: Barut, Top ve Tüfek: Osmanl Imparatorluğu'nun Askeri Gücü ve Silah Sanayisi, çev. Tanju Akad, İstanbul: Kitap Yayınevi, 2006.

Barkan, Ömer Lütfi: “Timar”, $\dot{I} A$, c. 12/1, s. 286-333.

Bir İstanbul Hanımefendisi Sâmiha Ayverdi'den Türkçe’nin Nakışları: Atasözleri, Deyimler, Tekerlemeler, Bilmeceler, haz. Kâzım Yetiş, İstanbul: Kubbealtı Neşriyat, 1993.

Boyraz, Arslan: "Köprülüzâde Fazıl Ahmet Paşa Devrinde (1069-1080) Vukuatı Tarihi, Transkripsiyon ve Değerlendirme”, (Yayımlanmamış Yüksek Lisans Tezi) İstanbul: Marmara Üniversitesi Türkiyat Araştırmaları Enstitüsü, 2002.

Chardin, Jean: Chardin Seyahatnamesi; İstanbul, Osmanl Toprakları, Gürcistan, Ermenistan, İran 1671-1673, çev. Ayşe Meral, İstanbul: Kitap Yayınevi, 2014.

Cosmescu, Dragoş: Venetian Renaissance Fortifications in the Mediterranean, North Carolina: McFarland, 2016.

Çelik, Bülent: “Osmanlı Seferlerinin Lojistik Sorunlarına Kentli Esnafın Getirdiği Çözümler: Orducu Esnafı”, (Yayımlanmamış Doktora Tezi) Ankara: Ankara Üniversitesi Sosyal Bilimler Enstitüsü, 2002.

Çelik, Şenol: "Orducu”, TDV İslàm Ansiklopedisi, XXXIII (İstanbul 2007), s. 370-373.

Çelik, Şenol: "Osmanlı Sefer Organizasyonunda Orducu Esnafı ve İstanbul Orducuları", Eskiçăg’dan Modern Çăg’a Ordular: Oluşum, Teşkilât ve Işlev, ed. Feridun Emecen, İstanbul: Kitabevi, 2008, s. 355-386.

Çevik, Murtaza: “78/1 Numaralı Kayseri Şer’iyye Sicili (H. 1078-1079/M. 1668), Transkripsiyon ve Değerlendirme”, (Yayımlanmamış Yüksek Lisans Tezi) Kayseri: Erciyes Üniversitesi Sosyal Bilimler Enstitüsü, 2009.

De la Guillatiere, Monsieur: An Account of a Late Voyage to Athens, containing the estate both ancient and modern of that famous city, and of the present empire of the Turks, the life of the now Sultan Mahomet the IV, with the Ministry of the Grand Vizier Coprogli Achmet Pacha: also the most remarkable passages in the Turkish camp at the siege of Candia and divers other particularities of the affairs of the port, ed. ve çev. J. M., Londra: Herringman, 1676. 
Defterdar Sarı Mehmed Paşa: Zübde-i Vekayiât, Tahlil ve Metin (1066-1116/1656-1704), haz. Abdülkadir Özcan, Ankara: Türk Tarih Kurumu, 1995.

Evliya Çelebi b. Derviş Mehemmed Zillî: Evliyâ Çelebi Seyahatnâmesi, 8. Kitap: Topkapı Sarayı Kütüphanesi Bağdat 308 Numaralı Yazmanın Transkripsiyonu-Dizini, haz. Seyit Ali Kahraman-Yücel Dağlı-Robert Dankoff, İstanbul: Yapı Kredi Yayınları, 2003.

Genç, Serdar: Lale Devrinde Savaş, Iran Seferlerinde Organizasyon ve Lojistik, İstanbul: Kitap Yayınevi, 2013.

Göger, Veysel: “16. Yüzyıl Osmanlı Kale Kuşatmaları (Strateji, Taktik, Kuşatma Aşamalar1 ve Teknolojisi)”, (Yayımlanmamıs Doktora Tezi) İstanbul: Marmara Üniversitesi Türkiyat Araştırmaları Enstitüsü, 2014.

Göger, Veysel: “Osmanlıların Kandiye Kuşatması Sırasında Girit Adası'nda Kurduklar1 Tophane (1666-1670)”, Türk Kültürü İncelemeleri Dergisi, 38 (İstanbul 2018), s. 107-126.

Gülsoy, Ersin: “Girit Seferleri Gazavâtnâmeleri ve Özellikler”, Yeni Türkiye, 33 (Ankara 2000), s. 640-642.

Gülsoy, Ersin: Giritin Fethi ve Adada Osmanlı İdaresinin Kurulması (1645-1670), İstanbul: TATAV, 2004.

Kolovos, Elias: "A Town For the Besiegers: Social Life and Marriagein Ottoman Candia Outside Candia (1650-1669)", The Eastern Mediterranean Under Ottoman Rule: Crete, 1645-1840 (Halcyon Days in Crete VI A Symposium Held in Rethymno13-15 January 2006), Antonis Anastasopoulos (ed.), Rethymno: Crete University Press, 2008, s. 103-175.

Levend, Agâh Sırrı: Gazavât-nâmeler ve Mihaloğlu Ali Bey’in Gazavât-nâmesi, Ankara: Türk Tarih Kurumu, 2000.

Murphey, Rhoads: Osmanlida Ordu ve Savaş 1500-1700, çev. M. Tanju Akad, İstanbul: Homer Yayınevi, 2007.

Mustafa bin Musa: Tarih-i Sefer ve Feth-i Kandiye, Fazıl Ahmed Paşannn Girit Seferi ve Kandiye’nin Fethi, 1666-1669, haz. Meltem Aydın, İstanbul: IQ Kültür Sanat Yayınları, 2016.

Oluk, Fahri: “Camiü’d-Düvel, Sultan IV. Mehmet Dönemi Tercüme, Metin ve Değerlendirme”, (Yayımlanmamış Doktora Tezi) Kayseri: Erciyes Üniversitesi Sosyal Bilimler Enstitüsü, 2011.

Orhonlu, Cengiz: Osmanlı Imparatorluğu’nda Derbend Teşkilâtı, İstanbul: Eren Yayıncılık, 1990.

Özcan, Abdülkadir: "Serdengeçti”, TDV İslâm Ansiklopedisi, XXXVI (İstanbul 2009), s. 554-555.

Öztürk, Temel: Osmanlaların Kuzey ve Doğu Seferlerinde Savaş ve Trabzon, Trabzon: Serander Yayınları, 2011. 
Pakalın, Mehmet Zeki: Osmanlı Tarih Deyimleri ve Terimleri Sözlüğ̈̈, c. II, İstanbul: MEB, 1983.

Parker, Geoffrey: Askeri Devrim: Batı̇nın Yükselişinde Askeri Yenilikler 1500-1800, çev. Tuncay Zorlu, İstanbul: Küre Yayınları, 2006.

Pollak, Martha: Cities at War in Early Modern Europe, New York: Cambridge University Press, 2010.

Pul, Ayşe: “Girit Savaşı İle İlgili Bir Türk Kaynağının Tahlili (TTK Kütüphanesi’nde Bulunan Girid Fethi Tarihi Başlıklı Yazma)”, (Yayımlanmamış Doktora Tezi) Ankara: Ankara Üniversitesi Sosyal Bilimler Enstitüsü, 2004.

Râşid Mehmed Efendi: Târîh-i Râşid, c. I (1071-1114/1660-1703), haz. Abdülkadir Özcan, Yunus Uğur, Baki Çakır, Ahmet Zeki İzgöer, İstanbul: Klasik, 2013.

Setton, Kenneth M.: Venice, Austria and the Turks in the Seventeenth Century, Philadelphia: American Philosophical Society, 1991.

Sezer, Musa: “78/2 Numaralı Kayseri Şer’iyye Sicili (H. 1078-1079/M. 1668), Transkripsiyon ve Değerlendirme”, (Yayımlanmamış Yüksek Lisans Tezi) Kayseri: Erciyes Üniversitesi Sosyal Bilimler Enstitüsü, 2008.

Türkal, Nazire Karaçay: "Silahdar Fındıklılı Mehmed Ağa Zeyl-i Fezleke (1065-22 Ca.1106 / 1654-7 Şubat 1695) (Tahlil ve Metin)”, (Yayımlanmamış Doktora Tezi) İstanbul: Marmara Üniversitesi Türkiyat Araştırmaları Enstitüsü, 2012.

Yılmaz, Ozan: “'Gelenekten Deyişe’ Klasik Türk ve Fars Edebiyatlarının Ortak İfade Biçimlerinden 'Başa Toprak Saçmak'” TÜRÜK, Dil, Edebiyat ve Halkbilimi Araştırmaları Dergisi, 2 (2013), s. 336-350.

Yücel, Abubekir Sıddık: "Mühürdâr Hasan Ağa’nın Cevâhirü’t-Tevârîh'i”, (Yayımlanmamış Doktora Tezi) Kayseri: Erciyes Üniversitesi Sosyal Bilimler Enstitüsü, 1996.

Zinkeisen, Johann Wilhelm: Osmanlı Imparatorluğu Tarihi (1623-1669), çev. Nilüfer Epçeli, c. 4, İstanbul: Yeditepe Yayınları, 2011. 
TAŞ YASDANUP TOPRAK DÖŞENENLER

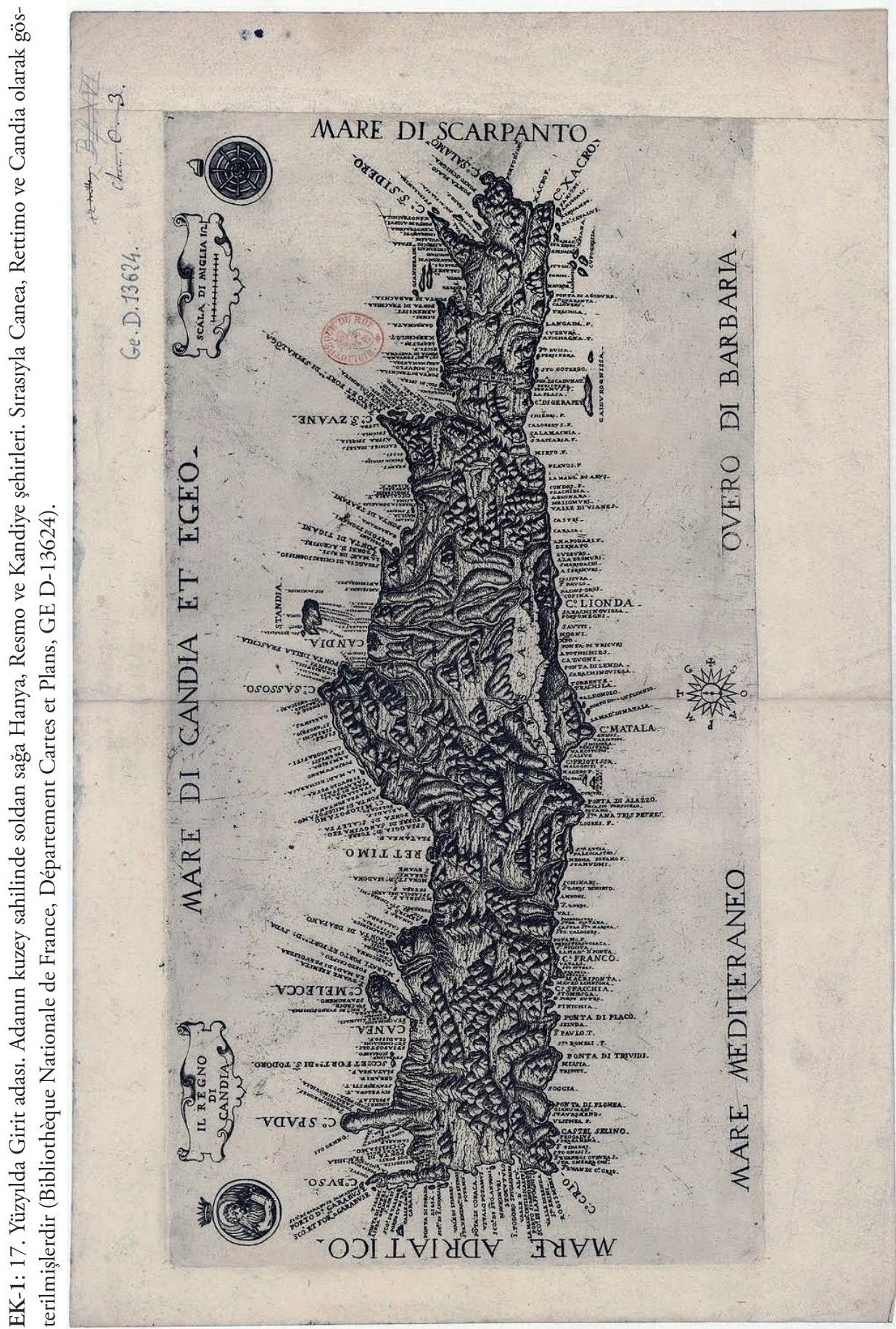


VEYSEL GÖGER

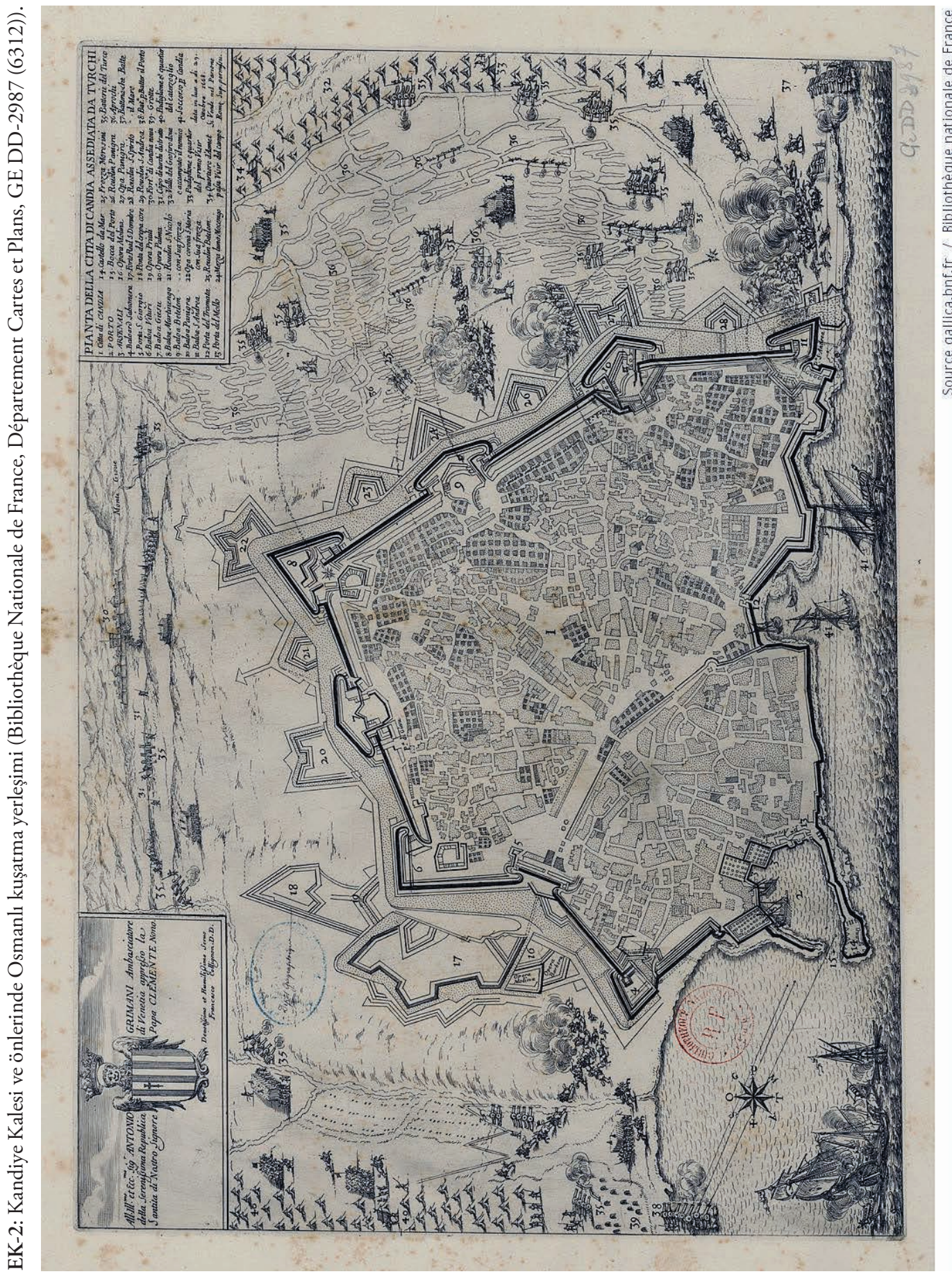


TAŞ YASDANUP TOPRAK DÖŞENENLER

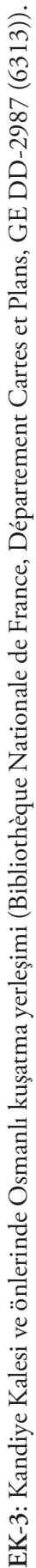

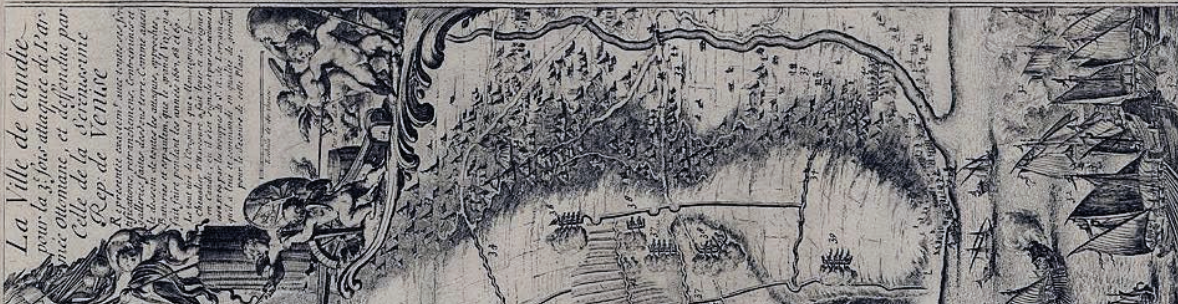

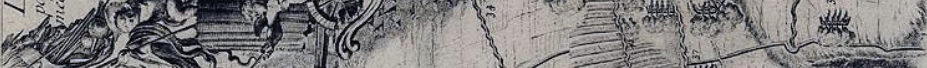
$y=2 x x_{0}$ dx
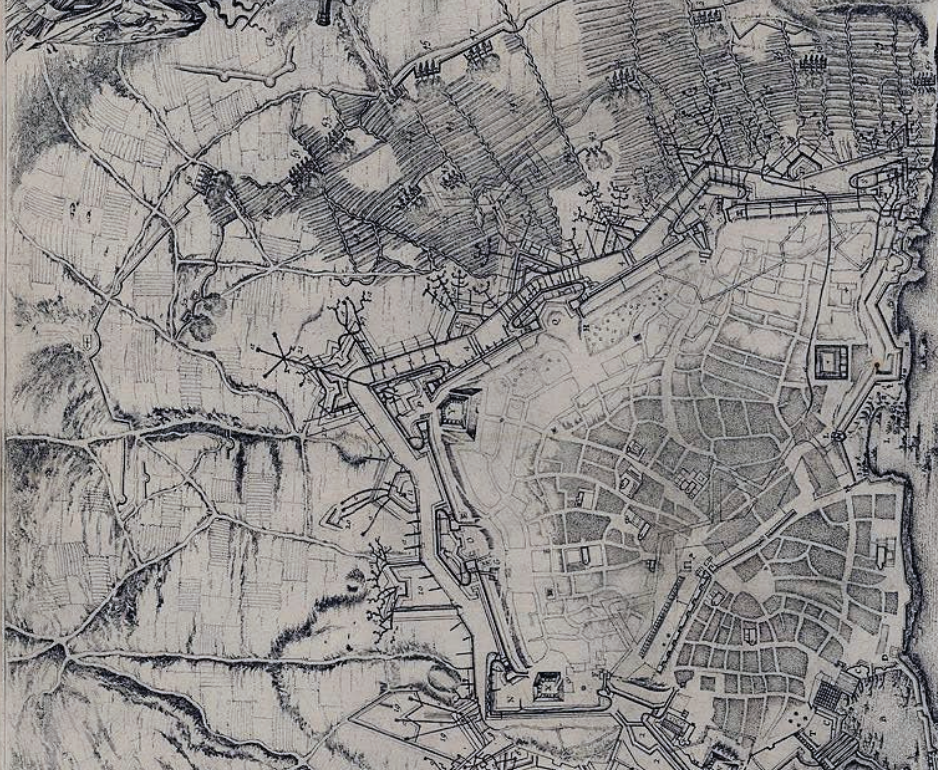

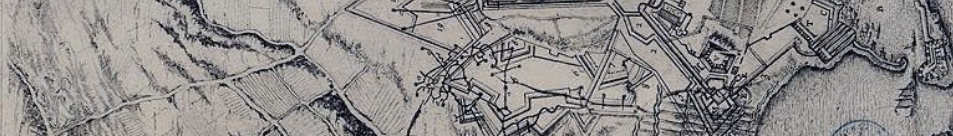

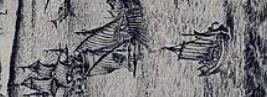
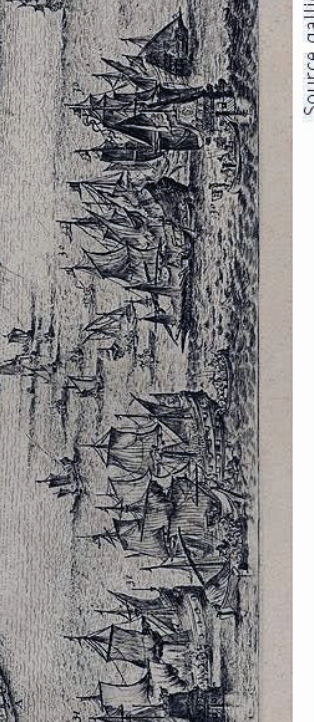

Fin.

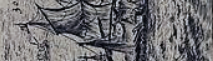

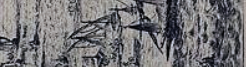

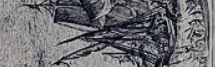

(1) $\rightarrow$.

W.

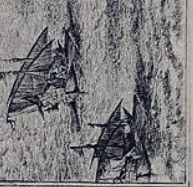

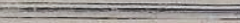

\section{.}

